In cooperation with the City of Columbus, Ohio

\title{
Occurrence of Antibiotic Compounds in Source Water and Finished Drinking Water from the Upper Scioto River Basin, Ohio, 2005-6
}

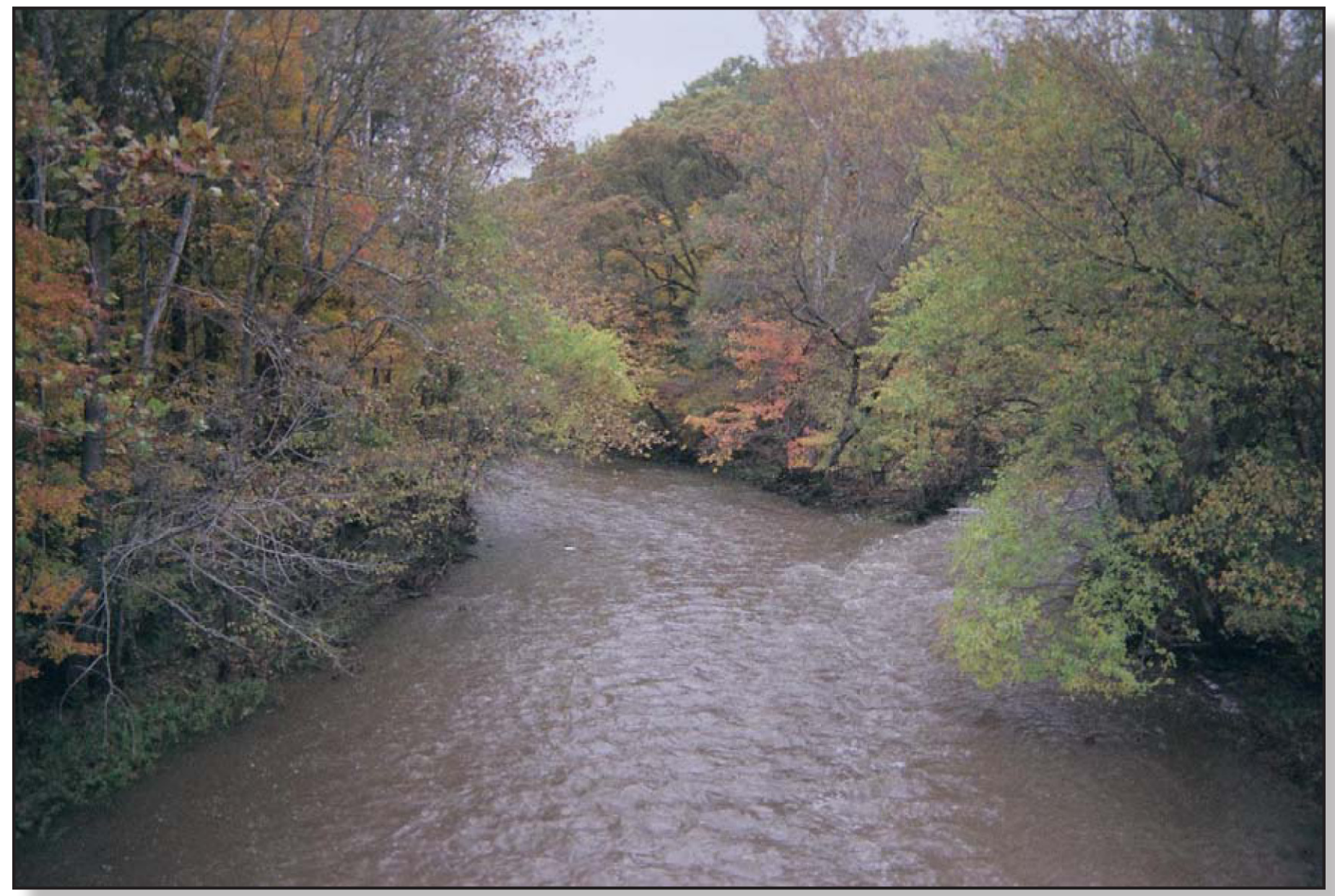

Scientific Investigations Report 2010-5083 



\section{Occurrence of Antibiotic Compounds in Source Water and Finished Drinking Water from the Upper Scioto River Basin, Ohio, 2005-6}

By Dennis P. Finnegan, Laura A. Simonson, and Michael T. Meyer

In cooperation with the City of Columbus, Ohio

Scientific Investigations Report 2010-5083 


\section{U.S. Department of the Interior \\ KEN SALAZAR, Secretary \\ U.S. Geological Survey \\ Marcia K. McNutt, Director}

\section{U.S. Geological Survey, Reston, Virginia: 2010}

For more information on the USGS — the Federal source for science about the Earth, its natural and living resources, natural hazards, and the environment, visit http://www.usgs.gov or call 1-888-ASK-USGS.

For an overview of USGS information products, including maps, imagery, and publications, visit http://www.usgs.gov/pubprod

To order this and other USGS information products, visit http://store.usgs.gov

Any use of trade, product, or firm names is for descriptive purposes only and does not imply endorsement by the U.S. Government.

Although this report is in the public domain, permission must be secured from the individual copyright owners to reproduce any copyrighted materials contained within this report.

Suggested citation:

Finnegan, D.P., Simonson, L.A., and Meyer, M.T., 2010, Occurrence of antibiotic compounds in source water and finished drinking water from the upper Scioto River Basin, Ohio, 2005-6: U.S. Geological Survey Scientific Investigations Report 2010-5083, 16 p. plus appendixes. 


\section{Contents}

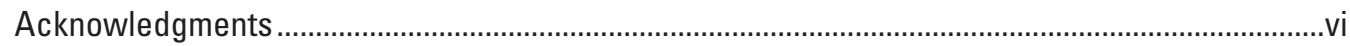

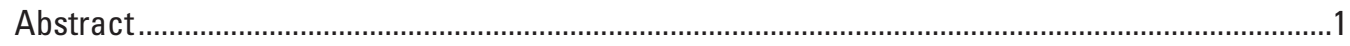

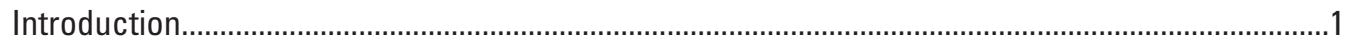

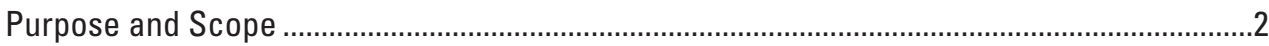

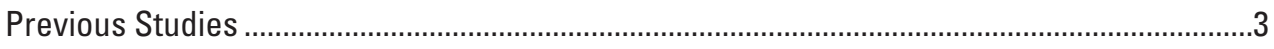

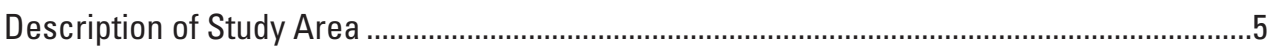

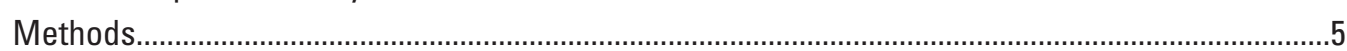

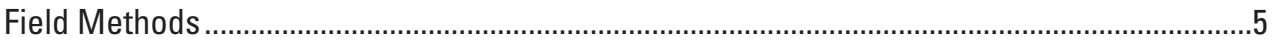

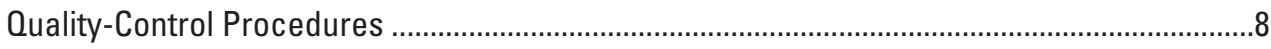

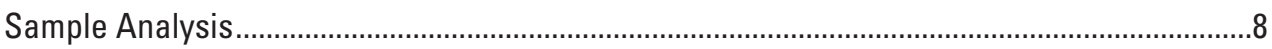

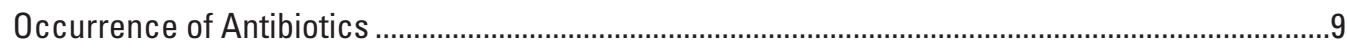

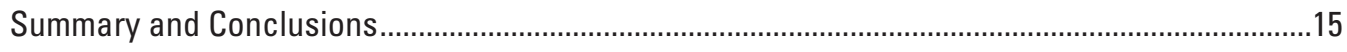

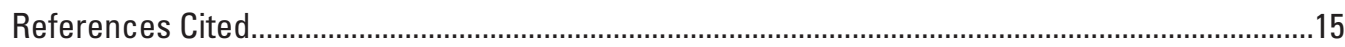

Appendix 1. Water-Quality Analyses and Quality-Control Results................................................18

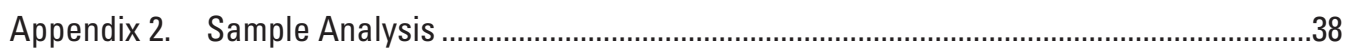

\section{Figures}

1. Graph showing detection frequencies for selected antibiotics. $A$, The upper Scioto River Basin study, 2005-6. B, The National Reconnasiance,1999-2000 .4

2-3 Maps showing:

2.. Land use in and around study area, upper Scioto River Basin, central Ohio

3. Sampling locations, upper Scioto River Basin, Ohio, 2005-6 ....................................

4-8. Graphs showing:

4. Occurrence and concentrations of antibiotic compounds at sites in the upper Scioto River Basin, Ohio, and corresponding detection frequencies evaluated against each compound's miminum reporting level ....

5. Total number of detections (61) by antibiotic group for collection sites in the upper Scioto River Basin, 2005-6

6. Summary of antibiotic compounds detected in water samples collected from the upper Scioto River Basin, Ohio, 2005-6 .

7. Numbers of detections of antibiotic compounds by sampling site and date in source and finished waters of the upper Scioto River Basin, central Ohio, 2005-6.

8. Total number of detections at all sites, by season, in the upper Scioto River Basin, central Ohio, 2005-6. 


\section{Tables}

1. Major antibiotic groups and some common uses in human therapy and animal husbandry

2. Major groups of antibiotics and degradation products targeted by chemical analysis of water samples collected from the upper Scioto River Basin, Ohio, 2005-6.

3. Sampling-locations descriptions for antibiotic samples collected in the upper Scioto River Basin, Ohio, 2005-6. .8

4. Total numbers of detections of antibiotic compounds in source- and finished- water sites from the Scioto River Basin, Ohio, 2005-6 10

\section{Appendix Tables}

1-1. Field parameters from sampling locations in the upper Scioto River Basin, Ohio, 2005-6 $18-19$

1-2. Water-quality analyses from sampling locations in the upper Scioto River Basin, Ohio, 2005-6

1-3. Quality-control analyses from sampling locations in the upper Scioto River Basin, Ohio, 2005-6

2-1. Mobile phases used in the liquid chromatography/electrospray ionization-mass spectrometry (LC/ESI-MS) techniques for three common antibiotic groups 


\section{Conversion Factors and Abbreviations}

\begin{tabular}{lcl}
\hline \multicolumn{1}{c}{ Multiply } & By & \multicolumn{1}{c}{ To obtain } \\
\hline millimeter $(\mathrm{mm})$ & 0.03937 & inch (in.) \\
mile $(\mathrm{mi})$ & 1.609 & kilometer $(\mathrm{km})$ \\
\hline \multicolumn{3}{c}{ Area } \\
\hline square mile $\left(\mathrm{mi}^{2}\right)$ & 259.0 & hectare $(\mathrm{ha})$ \\
square mile $\left(\mathrm{mi}^{2}\right)$ & 2.590 & square kilometer $\left(\mathrm{km}^{2}\right)$ \\
\hline & Volume & \\
\hline milliliter $(\mathrm{mL})$ & .03381 & fluid ounce $(\mathrm{oz})$ \\
microliter $(\mu \mathrm{L})$ & .001 & milliliter \\
liter $(\mathrm{L})$ & .2642 & gallon $(\mathrm{gal})$ \\
\hline & Flow rate & \\
\hline cubic foot per second $\left(\mathrm{ft}^{3} / \mathrm{s}\right)$ & .02832 & cubic meter per second $\left(\mathrm{m}^{3} / \mathrm{s}\right)$ \\
\hline
\end{tabular}

Temperature in degrees Celsius $\left({ }^{\circ} \mathrm{C}\right)$ may be converted to degrees Fahrenheit $\left({ }^{\circ} \mathrm{F}\right)$ as follows:

${ }^{\circ} \mathrm{F}=\left(1.8 x^{\circ} \mathrm{C}\right)+32$

Specific conductance is given in microsiemens per centimeter at 25 degrees Celsius $\left(\mu \mathrm{S} / \mathrm{cm}\right.$ at $\left.25^{\circ} \mathrm{C}\right)$.

Concentrations of chemical constituents in water are given in milligrams per liter $(\mathrm{mg} / \mathrm{L})$, micrograms per liter $(\mu \mathrm{g} / \mathrm{L})$, or nanograms per milliliter $(\mathrm{ng} / \mathrm{mL})$.

Pore sizes of filters are given in micrometers ( $\mu \mathrm{m}$; a micrometer is 0.001 millimeter). 


\section{Acknowledgments}

The authors thank Matt Steele and Rod Dunn from the City of Columbus, Division of Power and Water, for their assistance in project planning and report review 


\title{
Occurrence of Antibiotic Compounds in Source Water and Finished Drinking Water from the Upper Scioto River Basin, Ohio, 2005-6
}

\author{
By Dennis P. Finnegan, Laura A. Simonson, and Michael T. Meyer
}

\section{Abstract}

The occurrence of antibiotics in surface water and groundwater in urban basins has become a topic of increasing interest in recent years. Little is known about the occurrence, fate, or transport of these compounds and the possible health effects in humans and aquatic life. The U.S. Geological Survey, in cooperation with the City of Columbus, Division of Power and Water, did a study to provide a synoptic view of the occurrence of antibiotics in source and finished waters in the upper Scioto River Basin.

Water samples were collected seasonally-winter (December 2005), spring (May 2006), summer (August 2006) and fall (October 2006) — at five surface-water sites, one groundwater site, and three water-treatment plants (WTPs). Within the upper Scioto River Basin, sampling at each WTP involved two sampling sites: a source-water intake site and a finished-water site.

One or more antibiotics were detected at 11 of the 12 sampling sites. Of the 49 targeted antibiotic compounds, 12 (24 percent) were detected at least one time for a total of 61 detections overall. These compounds were azithromycin, tylosin, erythromycin- $\mathrm{H}_{2} \mathrm{O}$, erythromycin, roxithromycin, ciprofloxacin, ofloxacin, sulfamethazine, sulfamethoxazole, iso-chlorotetracycline, lincomycin, and trimethoprim. Detection results were at low levels, with an overall median of $0.014 \mu \mathrm{g} / \mathrm{L}$. Hap Cremean WTP had the fewest detections, with two source-water detections of sulfamethoxazole and azithromycin and no detections in the finished water. Of the total of 61 detections, 31 were in the winter sample run. Sulfamethoxazale and azithromycin detections represent 41 percent of all antibiotic detections. Azithromycin was detected only in the winter sample. Some antibiotics, such as those in the quinoline and tetracycline families, dissipate more quickly in warm water, which may explain why they were detected in the cool months (winter, spring, and fall) and not in the summer. Antibiotic data collected during this study were compared to antibiotic data collected in previous national, regional, and local studies. Many of the same antibiotic compounds detected in the upper Scioto River Basin also were detected in those investigations.

\section{Introduction}

A national reconnaissance study done during 1999-2000 revealed that a variety of chemicals used daily in homes, industry, and agriculture and including antimicrobials, detergents, disinfectants, fragrances, fire retardants, prescription and nonprescription drugs, and pesticides can enter streams (Kolpin and others, 2002). These chemicals, which can also affect groundwater, are often referred to as emerging contaminants (ECs), organic wastewater compounds (OWCs), and pharmaceuticals and personal care products (PPCPs); they can be released into the environment by various discharges (industrial facilities, animal feedlots, wastewater-treatment plants, septic disposal systems) and land applications (sludge, biosolids, or animal waste) in urban or agricultural areas. Antibiotics are considered to be ECs and can now be detected at low concentrations in surface water and groundwater (U.S. Geological Survey, 2007). A recent study in Ohio detected antibiotics at low concentrations (parts per billion) in streams draining the Great and Little Miami River Basins (Rowe and others, 2004).

The potential effects on humans and biota resulting from environmental exposure to antibiotics are not well understood, but ongoing research indicates possible chronic effects from long-term exposure to even trace concentrations (Kolpin and others, 2002). Large quantities of antibiotics are administered every year to humans and animals to prevent and treat diseases and infection (table 1). For some confined livestock, antibiotics are used to promote growth (Huang and others, 2001). Little is known about the effects of many other individual chemicals or about the potential additive or synergistic effects of mixtures of these chemicals. As much as 90 percent of some administered antibiotics can be excreted without undergoing metabolism, which makes them available to bioaccumulate or biomagnify in aquatic or terrestrial organisms (Halling-Sørensen and others, 1998). Few studies have addressed the occurrence, fate, or transport of antibiotic compounds in the environment, and water-quality standards to protect human or aquatic health have not been established for most of these chemicals. 
In the recent past, analytical methods were not available to accurately detect extremely low concentrations of antibiotic compounds in water and provide a basis for drinking-water standards. Analytical methods have now been improved to include a broader range of antibiotic compounds for analysis, as well as the ability to report detections in concentrations as low as parts per billion (ppb). Development of drinking-water standards generally involves long-term exposure studies of known health effects; as a result, no Maximum Contaminant Levels (MCLs), Health Advisory Levels (HALs), or HealthBased Screening Levels (HBSLs) for most of these compounds have yet been established (Kolpin and others, 2002).

Although human health and environmental effects of antibiotics are not well understood, other chemicals - such as the antimicrobial compound triclosan found in many liquid soaps, dishwasher powders, and plastics — are suspected of increasing antibiotic resistance in bacteria in the environment, and similar concerns have been raised by large-scale use of veterinary antibiotics in confined animal feeding operations (Kolpin and others, 2002).

As a result of attention on the issue of antibiotics in public water supplies (Stratton, 2002), the City of Columbus, Ohio, received inquiries regarding the presence of antibiotics, and other wastewater chemicals in city water supplies. Consequently, the U.S. Geological Survey (USGS), in cooperation with the City of Columbus, collected water samples from locations in the upper Scioto River Basin from December 2005 to October 2006 to determine the occurrence and distribution of antibiotic compounds in source water from the City of Columbus, Ohio, during different hydrologic conditions. Samples were collected from five surface-water sites, one groundwater site, and two sites - a source and finished water site-at each of three water-treatment plants (WTPs). Samples were analyzed for 49 antibiotic compounds, which were grouped into five classes: macrolides, beta lactams, quinolines, sulfonamides, and tetracyclines (table 2). A sixth group analyzed for, "other antibiotics," included compounds such as carbadox and lincomycin (table 2).

\section{Purpose and Scope}

The purpose of this report is to present and describe data from the 2005-6 study. Results from this study address data gaps from a previous reconnaissance effort in 2001 (see "Previous Studies" section; Kolpin and others, 2002) and complement ongoing efforts by the USGS Toxic Substances Hydrology Program and the USGS National WaterQuality Assessment Program to characterize the distribution and occurrence of antibiotics and OWCs in the Nation's water resources.

Table 1. Major antibiotic groups and some common uses in human therapy and animal husbandry.

[Sources: Hooper, D.C., 1998; Smilack, J.D., 1999; Čižman and others, 2001; Huang and others, 2001; Lipsitch and others, 2002; Casewell and others, 2003; and Scholar, E.M., 2003]

Antibiotic group

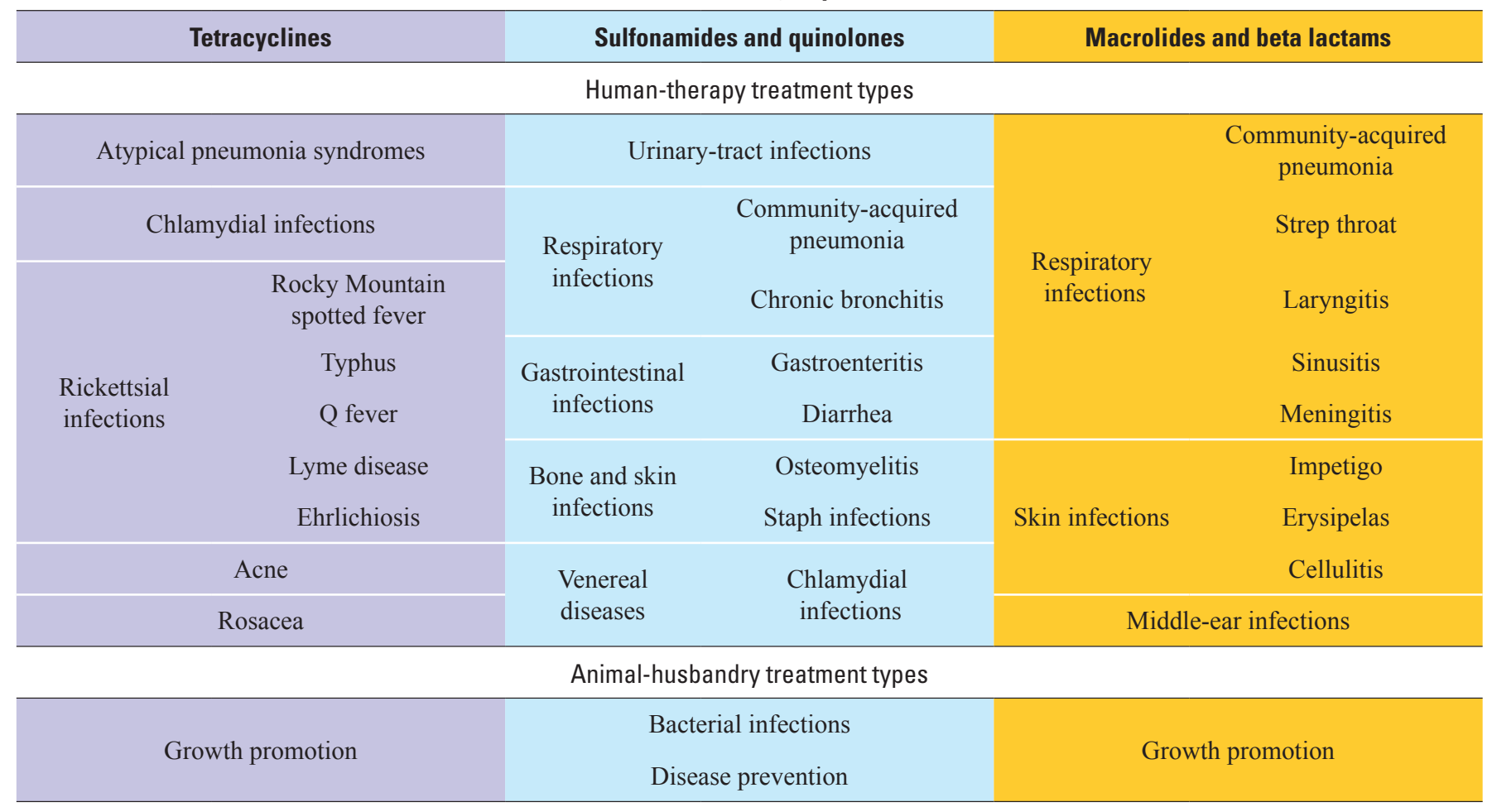




\section{Previous Studies}

Investigations into the occurrence of ECs in surface waters have been done at national, regional, and local levels nationwide, and results indicate that antibiotic compounds are not uncommon in groundwater and surface water. In 2002, USGS reported on the first national reconnaissance of the occurrence of pharmaceuticals, hormones, and other OWCs in water resources (Kolpin and others, 2002). A network of 139 streams across 30 states was sampled and analyzed for 95 ECs. Some commonly detected antibiotics reported in that study were lincomycin (19.2 percent detection) and tylosin (13.5 percent detection; fig.1). Of the antibiotics sampled for, 45 percent were detected, the highest frequency being for erythromycin $-\mathrm{H}_{2} \mathrm{O}$ at roughly 21.5 percent. Most detections were at low concentrations; however, chronic effects from low-level environmental exposure have potential to promote antibiotic resistance (Kolpin and others, 2002).

At the regional level, brief investigations into ECs in the Stillwater River Basin and the Great Miami River Basin were completed in 2000. Thirty samples collected from subbasins in the Stillwater River Basin after a single high-flow event revealed multiple lincomycin detections and an erythromycin$\mathrm{H}_{2} \mathrm{O}$ detection in combination with lincomycin. Lincomycin ( 23.5 percent) was found at similar frequencies in this regional study (Rowe and others, 2004) and the national investigation (Kolpin and others, 2002). Trace amounts of sulfamethazine and sulfadimethoxine also were detected in spring runoff samples in the Stillwater River Basin (Rowe and others, 2004).

In 2001, the USGS performed a small-scale local reconnaissance study within the current study unit boundaries to evaluate the presence of antibiotics in source water and finished drinking water supplied by the City of Columbus. One to three samples were collected at three surface-water sites (Powder Lick Run near Summersville, Ohio; Mill Creek below Marysville, Ohio; and Scioto River near Prospect, Ohio) in the Scioto River Basin upstream from the sourcewater intake to the Dublin Road WTP. In addition, source- and finished-water samples were collected at the Dublin Road and Hap Cremean WTPs. No antibiotics were detected at any of the three surface-water sites. However, three antibiotic compounds were detected in one sample event (Dec. 5, 2001) at the Dublin Road WTP: lincomycin $(0.03 \mu \mathrm{g} / \mathrm{L})$ and sulfadimethoxine $(0.01 \mu \mathrm{g} / \mathrm{L})$ were detected in the source water, and virginiamycin $(0.15 \mu \mathrm{g} / \mathrm{L})$ was detected in the finished water (USGS Ohio Water Science Center, unpub. data, 2001).
Table 2. Major groups of antibiotics and degradation products targeted by chemical analysis of water samples collected from the upper Scioto River Basin, Ohio, 2005-6.

\begin{tabular}{|c|}
\hline $\begin{array}{c}\text { Macrolides and } \\
\text { degradation products }\end{array}$ \\
\hline Azithromycin \\
\hline Erythromycin \\
\hline Erythromycin- $\mathrm{H}_{2} 0$ \\
\hline Roxithromycin \\
\hline Tylosin \\
\hline Virginiamycin \\
\hline Beta Lactams \\
\hline Amoxicillin \\
\hline Ampicillin \\
\hline Cefotaxime \\
\hline Cloxacillin \\
\hline Oxacillin \\
\hline Penicillin G \\
\hline Penicllin V \\
\hline Quinolines \\
\hline Ciprofloxacin \\
\hline Clinafloxacin \\
\hline Flumequine \\
\hline Lomefloxacin \\
\hline Norfloxacin \\
\hline Ofloxacin \\
\hline Oxolinic Acid \\
\hline Sarafloxacin \\
\hline Sulfonamides \\
\hline Sulfachlorpyradazine \\
\hline Sulfadiazine \\
\hline Sulfadimethoxine \\
\hline Sulfamerazine \\
\hline Sulfamethazine \\
\hline Sulfamethoxazole \\
\hline Sulfathiazole \\
\hline
\end{tabular}

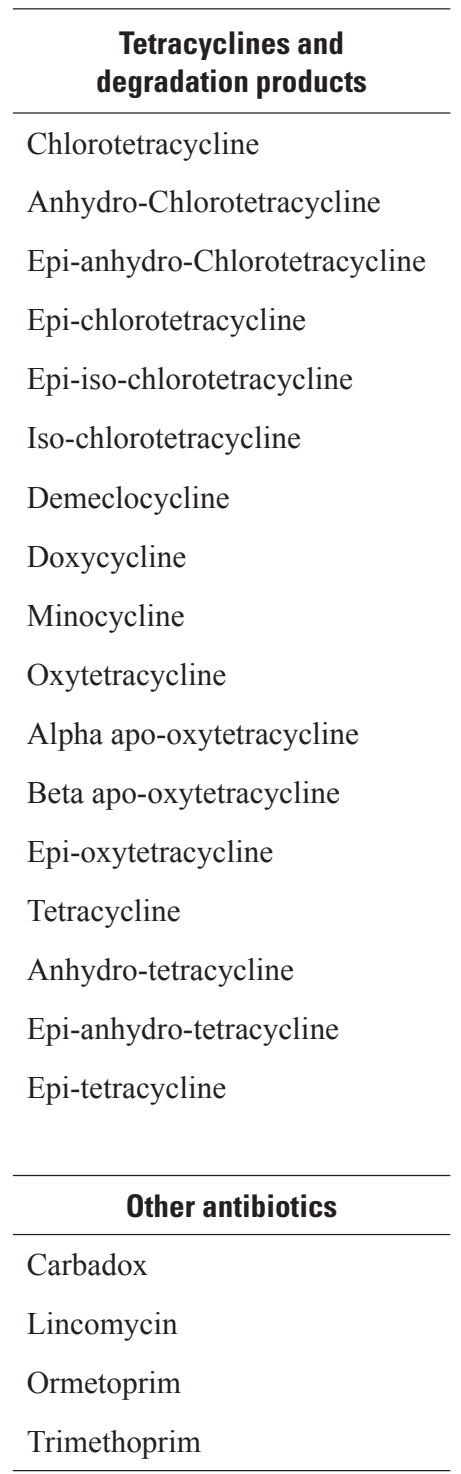




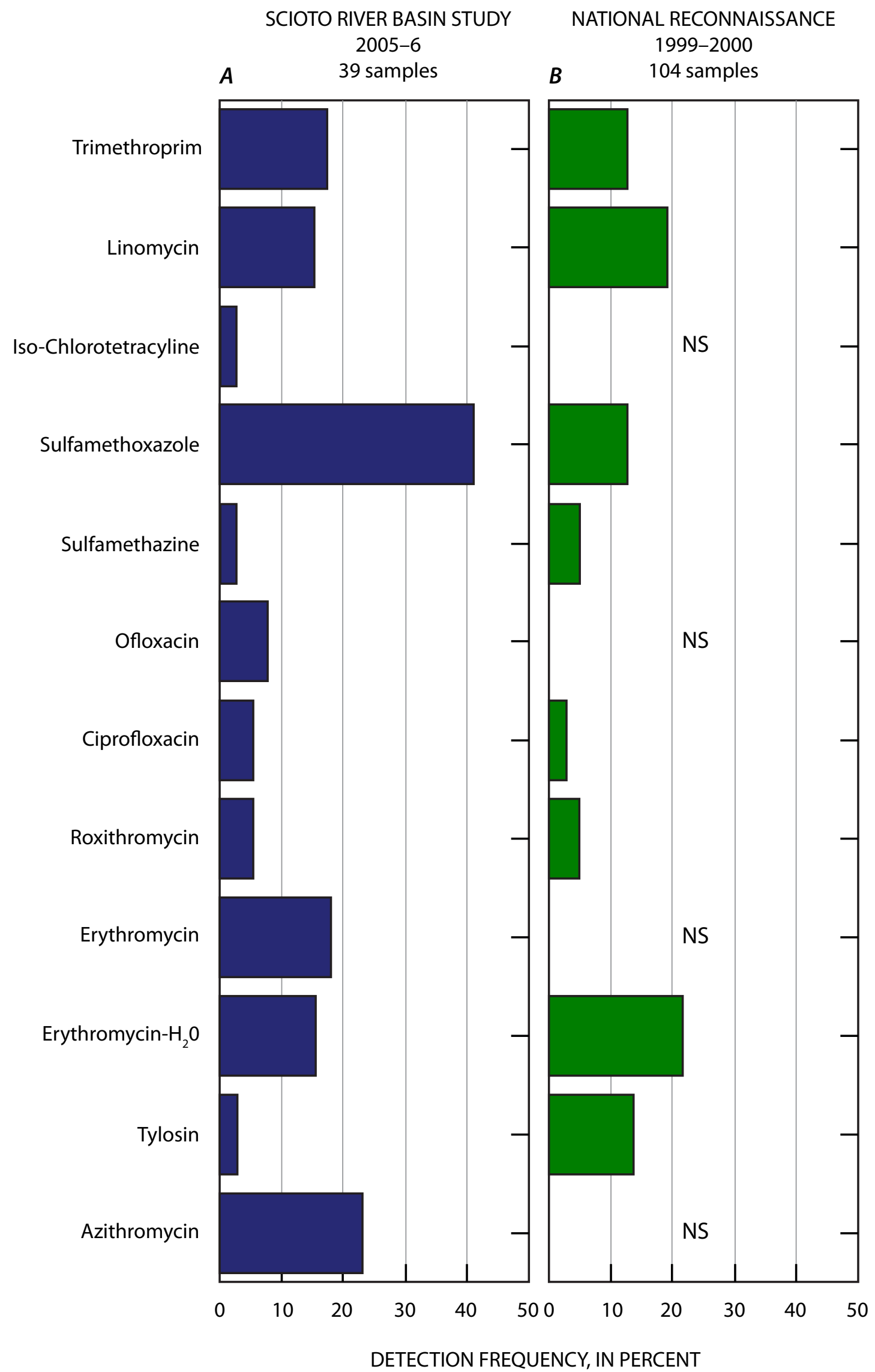

Figure 1. Detection frequencies for selected antibiotics. A, The upper Scioto River Basin study, 2005-6. $B$, The National Reconnasiance,1999-2000 (Kolpin and others, 2002). (NS, not sampled for.) 


\section{Description of Study Area}

The upper Scioto River Basin drains approximately 2,300 $\mathrm{mi}^{2}$ of central and north-central Ohio, stretching from Crawford County at the northernmost point to Franklin County at the south (fig. 2). The Scioto is the longest free-flowing river in Ohio at $231 \mathrm{mi}$ long, and it is fed by 3,000 miles of tributaries that flow through central and north-central Ohio (Nature Conservancy, 2007; Resources First Foundation, 2007). The surficial geology of the Scioto River Basin consists of glacial and alluvial deposits (Oblinger and others, 1991). The Scioto River Basin is a largely agricultural area that includes numerous suburban communities north of Columbus (fig. 2). Drainage from agricultural, residential, municipal, and industrial activities in the basin results in runoff of nutrients, pesticides, and a variety of ECs to surface water (Rowe and others, 2004). The basin also contains confined animal feeding operations (CAFOs) and numerous wastewater-treatment plants that discharge into the Scioto River (fig. 2). The basin has a population of approximately 2 million people and is a major source of public drinking water; more than 20 municipal water systems draw surface water and groundwater from the Scioto River, its tributaries, or wells adjacent to its tributaries (Resources First Foundation, 2007). The City of Columbus draws 85 percent of the city's annual water supply (roughly 47.5 billion gallons of water) from three reservoirs in the Scioto River Basin - Griggs, O'Shaughnessy, and Hooverwhich have a combined storage capacity of about 27 billion gallons (Columbus Department of Public Utilities, 2009).

\section{Methods}

\section{Field Methods}

From December 2005 through October 2006 (water years 2006 and 2007), USGS personnel collected water samples to be analyzed for antibiotics at 12 selected sampling sites. Samples were collected on a quarterly schedule, in an attempt to capture ideal hydrologic conditions within each season. Field blanks and replicates were scheduled to be sampled in association with each environmental quarterly sample.

Surface-water samples were collected from farthest upstream to downstream and from west to east by using a depth- and width-integrated, equal-width-increment (EWI) method (Wilde and others, 2006). Two models of isokinetic samplers incorporating a 1-L Teflon bottle were used for surface-water collection: a DH-95 was used from a bridge, and a DH-81 was used for wading. The collected sample was composited into a Teflon churn splitter to obtain a homogeneous subsample (Wilde and others, 2006). The surface-water sites were (1) Powder Lick Run near Summersville, Ohio, (2) Mill Creek below Marysville, Ohio, (3) Big Walnut Creek at Sunbury, Ohio, (4) Scioto River near Prospect, Ohio, and (5) Scioto River downstream from Collector Well-104
(CW-104) (fig. 3, table 3). Groundwater samples were collected from site (6) Columbus Well Field Collector Well101 (CW-101) - in the Columbus South well field - which supplies groundwater to the Parsons Avenue WTP. This site was sampled by means of the grab-sample method from a constantly flowing spigot within the well house. Paired sourceand finished-drinking-water grab samples were collected at the Dublin Road Plant $(7,8)$, the Hap Cremean Plant $(9,10)$, and the Parsons Avenue Plant $(11,12)$ (fig. 3; table 3).

All samples were processed at the time of collection. Sample water was filtered through a $0.7-\mu \mathrm{m}$ baked glass-fiber filter and captured in two $125-\mathrm{mL}$, baked amber-glass bottles (Wilde and others, 2004). Samples were chilled and shipped overnight to the USGS Organic Geochemistry Research Group Laboratory (ORGL) in Lawrence, Kansas. Ancillary data collected at each site included temperature, $\mathrm{pH}$, specific conductance, and dissolved oxygen concentrations (appendix 1, table 1-1). Streamflow was measured at ungaged stream sites 1 and 2 (fig. 3; table3). Each sampling event required 1 week for collection and processing of samples from all 12 sites.

Because of somewhat atypical weather patterns, sample collection consisted of low-flow samples in December 2005 and August 2006, and runoff samples in May 2006 and October 2006. Also, because large CAFOs are present in the upper Scioto River Basin, an additional runoff sample was collected in August at the stream sites in the upper Scioto-Powder Lick Run near Summersville, Mill Creek below Marysville, Scioto River near Prospect, and the Dublin Road WTP sitesto facilitate assessment of runoff water quality. The remaining sites-Big Walnut Creek at Sunbury, the Columbus Well Field CW-101, Scioto River downstream from CW-104, and Hap Cremean and Parsons WTPs - were sampled once (May) during runoff conditions.

Seasonal runoff samples were scheduled for collection in May-June (to capture high flows early in the growing season) and July-August (to capture low flows later in the growing season). However, more importance was given to collecting at least one set of samples during each seasonal quarter than to sampling the types of hydrological events expected during those quarters. Atypical weather conditions resulted in samples being collected earlier or later than expected, whenever suitable low-flow or runoff conditions presented themselves. Stream runoff samples were collected during or immediately after significant rainfall. No threshold rainfall amount was defined for a triggered sampling run; seasonal timing, more than anything, with sufficient rainfall usually dictated when to sample. Source-water and finished-drinkingwater samples were collected 3-5 days later. In an effort to target worst-case conditions, samples were collected during periods when results of daily nitrate and pesticide monitoring done by the Columbus Division of Power and Water indicated that concentrations of agrochemicals were highest in the source water. Low-flow samples were collected in late summer in an effort to target periods when treated wastewater and septic-tank discharge likely represent a larger proportion of the total streamflow. 


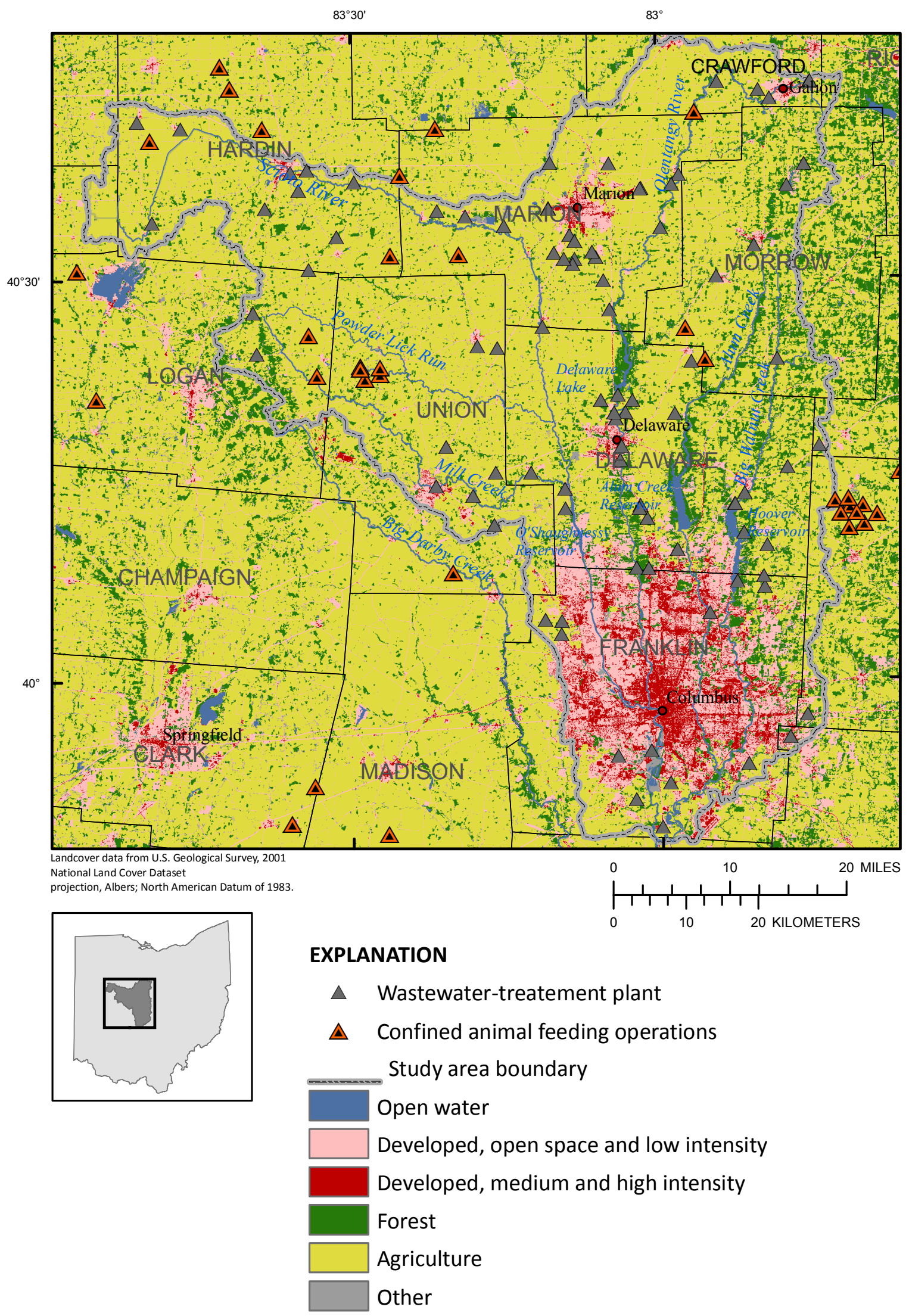

Figure 2. Land use in and around study area, upper Scioto River Basin, central Ohio. 


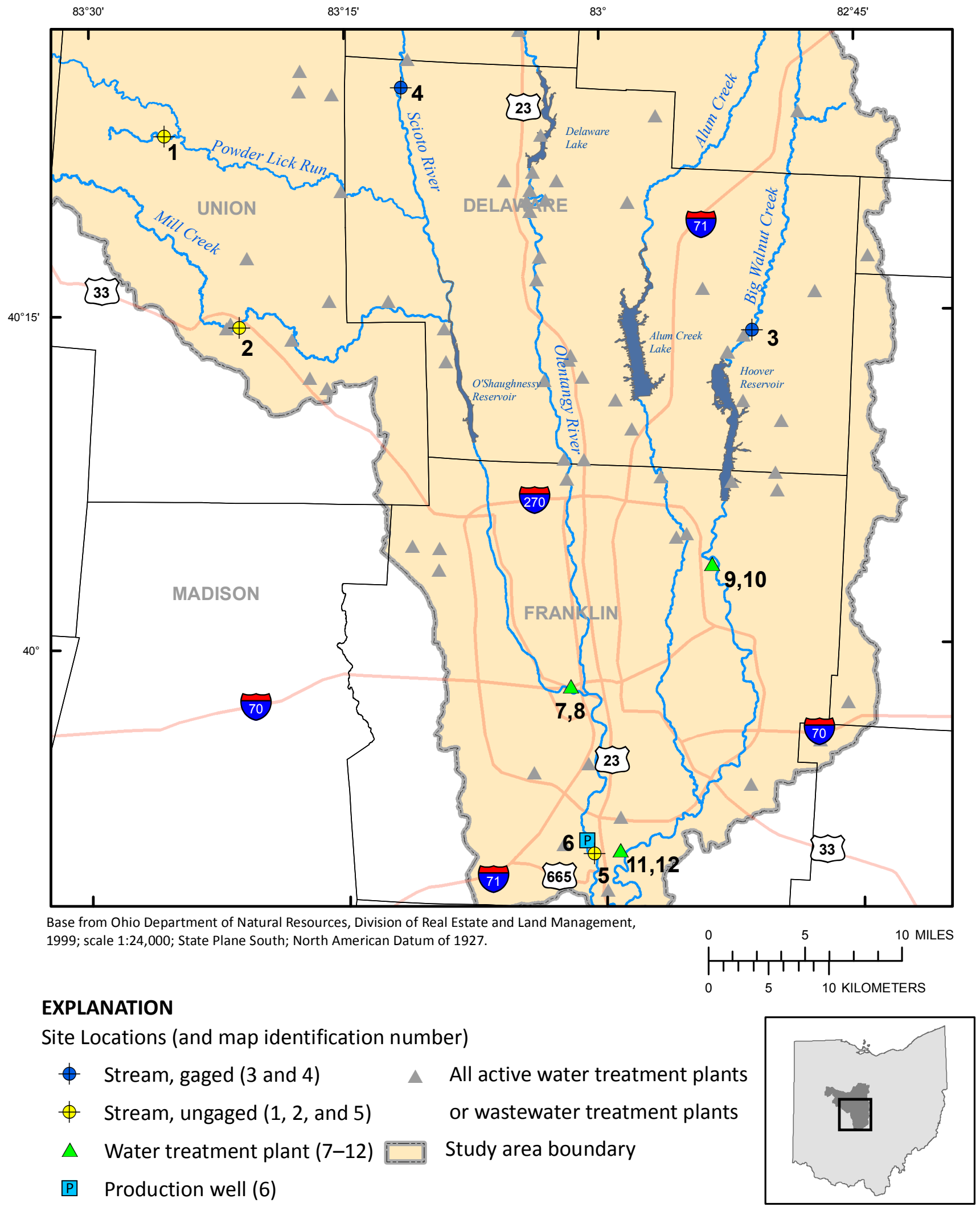

Figure 3. Sampling locations, upper Scioto River Basin, Ohio, 2005-6. (Numbers refer to site descriptions listed in table 3.) 
Table 3. Sampling-locations descriptions for antibiotic samples collected in the upper Scioto River Basin, 0hio, 2005-6.

[WTP, water-treatment plant; DS, downstream; CW, collector well; I, water intake; F, finished water]

\begin{tabular}{crll}
\hline $\begin{array}{c}\text { Map identification number } \\
\text { (location shown } \\
\text { in fig. 1) }\end{array}$ & $\begin{array}{r}\text { Station identification } \\
\text { number }\end{array}$ & \multicolumn{1}{c}{ Station name } & Relation to water-treatment plants \\
\hline 1 & 402302083254100 & Powder Lick Run near Summersville & Upstream from two WTPs. \\
2 & 401425083212500 & Mill Creek below Marysville & Upstream from two WTPs. \\
3 & 03228300 & Big Walnut Creek at Sunbury & Upstream from two WTPs. \\
4 & 03219500 & Scioto River near Prospect & Upstream from two WTPs. \\
5 & 395033083002900 & Scioto River DS from CW-104 & Downstream from one WTP. \\
6 & 395111083010600 & Columbus Well Field CW-101 & Adjacent to one WTP; well sample. \\
7 & 395813083020701 & Dublin Road WTP, I & At WTP. \\
8 & 395813083020702 & Dublin Road WTP, F & At WTP. \\
9 & 400336082533901 & Hap Cremean WTP I & At WTP. \\
10 & 400336082533902 & Hap Cremean WTP, F & At WTP. \\
11 & 395050082591301 & Parsons Avenue WTP, I & At WTP. \\
12 & 395050082591302 & Parsons Avenue WTP, F & At WTP. \\
\hline
\end{tabular}

\section{Quality-Control Procedures}

The quality-control (QC) procedures, which consisted of collecting and analyzing field blanks and replicates, followed a general quality-assurance/quality control protocol established for low-level organic analyses (parts per billion), the same protocol used for pesticides in the NAWQA Program (Mueller and others, 1997). Because many of the compounds being sampled for were commonly used products (personal care products and medicines, for example) and the risk for accidental contamination was high, a relatively large number of field blanks were collected compared to the NAWQA pesticide protocol for the project to identify and resolve possible contamination issues. Antibiotic field-blank samples represented about 15 percent of the environmental samples and yielded no detections. Replicates were samples that were collected in an identical manner as environmental samples as a measure of variability of the collection and analysis process. Two replicate samples were collected at study sites Columbus Well Field CW-101 and Powder Lick Run near Summersville, Ohio. The replicates indicated good reproducibility of laboratory results with an identical concentration of $(0.005 \mu \mathrm{g} / \mathrm{L})$ for lincomycin, the only detection from the two replicate samples. Field spikes - samples augmented with known quantities and concentrations of analytes or surrogates and often used as a
QC check in water-quality studies - were not collected during this investigation because there were no available field spike surrogates at the time of this investigation. All QC results for the study are listed in appendix 1, table 1-3.

\section{Sample Analysis}

Samples were analyzed at the ORGL in Lawrence, Kansas, for five classes of antibiotics - beta lactams, macrolides, quinolones, sulfonamides, and tetracyclines - by use of three online solid-phase extraction (SPE) methods and liquid chromatography/mass spectrometry (LC/MS) or LC/MS/MS. This approach can currently determine 49 commonly used human-therapy and animal-husbandry antibiotics, including some antibiotic breakdown products or degradates (tables 1 and 2). Beta lactams and macrolides (BLM), sulfonamides and quinolones (SQ), and the tetracyclines (TET) were analyzed separately by use of online solid SPE methods and liquid chromatography/electrospray ionization-mass spectrometry (LC/ESI-MS) in positive-ion mode. The reporting levels ranged from 0.01 to $0.005 \mu \mathrm{g} / \mathrm{L}$. (See appendix 2 for a more detailed description of BLM, SQ, and TET sample analysis; Meyer and others, 2007.) 


\section{Occurrence of Antibiotics}

Antibiotics detected in water samples collected for this study are summarized in table 4 . (The results of all antibiotic analyses are listed in appendix 1, table 1-2.) Of the 49 targeted antibiotic compounds, 12 (24 percent) were detected at least one time for a total of 61 detections overall (fig. 4; table 4; appendix 1, table 1-2). These compounds were trimethoprim, lincomycin, iso-chlorotetracycline, sulfamethoxazole, sulfamethazine, ofloxacin, ciprofloxacin, tylosin, roxithromycin, erythromycin- $\mathrm{H}_{2} \mathrm{O}$, erythromycin, and azithromycin (fig. 4). The concentrations of compounds detected ranged from 0.005 to $0.140 \mu \mathrm{g} / \mathrm{L}$ with a median value of $0.014 \mu \mathrm{g} / \mathrm{L}$ (fig. 4).

Antibiotic compound detections were similar to those detected in three previous antibiotic studies: Furlong and Boyd, 2002 (erythromycin, sulfamethoxazole, and trimethoprim); Rowe and others, 2004 (lincomycin and erythromycin- $\mathrm{H}_{2} \mathrm{O}$ ); and Kolpin and others, 2002 (trimethoprim, lincomycin, sulfamethoxazole, sulfamethazine, ciprofloxacin, roxithromycin, erythromycin- $\mathrm{H}_{2} \mathrm{O}$, and tylosin). Macrolides and sulfonamides were the most commonly detected antibiotic groups representing 41 percent (25) and 28 percent (17) of all detections, respectively (fig. 5). Huang and others (2001) suggested that sulfonamides, quinolines, and macrolides are likely water contaminants because they lack strong sediment sorption properties and thus are more likely to be found in the water column than in sediment. Azithromycin (9 detections) was most frequently detected macrolide, and sulfamethoxazole (16 detections) was the most commonly detected sulfonamide (figs. 4 and 6). Only one tetracycline compound was detected, iso-chlorotetracycline, a degradate product of chlorotetracycline (figs. 4 and 6). Huang and others (2001) noted that tetracyclines may persist for a significant period of time but are less mobile than other antibiotic groups, owing to sorption to soil. The antibiotic group "other" had 12 total detections; lincomycin and trimethoprim were both detected 6 times (figs. 5 and 6). Ciprofloxacin (2 detections) and ofloxacin (3 detections) were the only quinolines detected in the study area (figs. 4 and 6). No beta lactams were detected (fig. 5). Previous studies also indicate that beta lactams generally undergo hydrolysis fairly quickly under mildly acidic or basic conditions (Huang and others, 2001); thus, beta lactams are not likely to persist under $\mathrm{pH}$ conditions typical of the Scioto River Basin (appendix 1, table 1-1).

Sulfamethoxazole, an antibiotic compound that is often used in combination with other antibiotics to treat infections, had the single highest concentration at $0.14 \mu \mathrm{g} / \mathrm{L}$ (fig. 6). Sulfamethoxazole biodegrades slowly if at all, and sulfonamides, in general, exhibit weak sorption to soils. In addition, hydrolysis of sulfonamides at a neutral $\mathrm{pH}$ range is very slow and can be considered negligible, making them more likely to persist in solution (Huang and others, 2001).
At least one antibiotic was detected at 11 of the 12 sites; Hap Cremean F was the only site with no antibiotic detections (fig. 7). Scioto River near Prospect had the most detections overall at 17 and the most detections (7) on any one sampling date (on December 8, 2005). The Scioto River downstream from CW-104 had a total of 16 detections. Both sites had no less than three antibiotic compounds detected during all sampling events. Powder Lick Run near Summersville, a small intermittent stream, had trace detections of lincomycin, a growth promoter in livestock. This could be a possible connection to the presence of CAFOs upstream from the sampling site or other agricultural uses in the watershed (fig. 2).

Only two antibiotics, sulfamethoxazole and azithromycin, were detected at the Hap Cremean and Parsons Avenue WTPs, source-water intake sites (fig. 7). The Dublin Road WTP source-water intake site had the most antibiotics identified (6) for any one sampling event (May 24, 2006) and also had detections for all four sampling events; moreover, it is located between Scioto River nr Prospect and Scioto River downstream CW-104, both of which had numerous detections (17 and 16, respectively; figs. 3 and 7). The finished-water site at the Parsons Avenue WTP had detections of azithromycin, roxithromyocin and tylosin, whereas Hap Cremean had none. The Dublin Road WTP finished-water site (Dublin Road F) had one detection (azithromycin) in the December 2005 sample. Detention times for water-treatment processes were not included in the sampling protocol; therefore, conclusions about the efficiency of the WTPs were not drawn.

Data from surface-water sites were evaluated to determine potential seasonal variations in occurrence and concentrations (fig. 8). The number of antibiotic detections decreased from winter (31) to summer (6) and rose slightly in the fall (9). The winter sample (December 2005) yielded just over 50 percent of the total detections for this investigation in a relatively low-flow setting. All of the antibiotics detected during the course of this investigation (except for iso-chlorotetracycline) were detected in at least one water sample collected during the December 2005 sampling event. Other antibiotic studies (Furlong and Boyd, 2002) also have documented a large number of detections in the coolest months. Furlong and Boyd (2002) suggested that warm water temperatures found in the summer months cause an increase in biological activity and may significantly increase the degradation or biological uptake of some compounds. In addition, Huang and others (2001) found that tetracyclines and quinolines are susceptible to photodegradation, which may explain why they were detected in the cool fall through spring months of shorter photo periods and interference (shading from ice and fallen leaves) and not in the summer. The concentrations of antibiotic compounds were only slightly higher in the spring and summer samples than in the fall and winter samples. Hydrologic conditions were mixed (relatively low and high flows) during the sampling periods for both the spring and summer and the fall and winter. Galloway and others (2005) suggested a positive relation between water temperature and antibiotic concentration due to mobilization of certain antibiotic compounds. 
Table 4. Total numbers of detections of antibiotic compounds in source- and finished-water sites from the Scioto River Basin, Ohio, 2005-6.

[All values are in micrograms per liter; bold type indicates compounds that were detected at least once]

\begin{tabular}{lcc}
\hline \multicolumn{1}{c}{ Constituent } & $\begin{array}{c}\text { Detection } \\
\text { level }\end{array}$ & $\begin{array}{c}\text { Number of } \\
\text { detections }\end{array}$ \\
\hline Beta lactams & \\
\hline Amoxicillin & $<0.010$ & 0 \\
Ampicillin & $<0.010$ & 0 \\
Cefotaxime & $<0.010$ & 0 \\
Cloxacillin & $<0.010$ & 0 \\
Oxacillin & $<0.010$ & 0 \\
Penicillin G & $<0.010$ & 0 \\
Penicillin V & $<0.010$ & 0 \\
\hline
\end{tabular}

\begin{tabular}{lcc}
\hline \multicolumn{3}{c}{ Macrolides and degradation products } \\
\hline Azithromycin & $<0.005$ & 9 \\
Erythromycin & $<0.005$ & 7 \\
Erythromycin-H_0 & $<0.005$ & 6 \\
Roxithromycin & $<0.005$ & 2 \\
Tylosin & $<0.005$ & 1 \\
Virginiamycin & $<0.005$ & 0 \\
\hline
\end{tabular}

\begin{tabular}{lcc}
\hline & Quinolines & \\
\hline Ciprofloxacin & $<0.005$ & 2 \\
Clinafloxacin & $<0.005$ & 0 \\
Flumequine & $<0.005$ & 0 \\
Lomefloxacin & $<0.005$ & 0 \\
Norfloxacin & $<0.005$ & 0 \\
Oxfloxacin & $<0.005$ & 3 \\
Oxolinic Acid & $<0.005$ & 0 \\
Sarafloxacin & $<0.005$ & 0 \\
\hline
\end{tabular}

\begin{tabular}{lcc}
\hline \multicolumn{2}{c}{ Sulfonamides } & \\
\hline Sulfachlorpyradazine & $<0.005$ & 0 \\
Sulfadiazine & $<0.005$ & 0 \\
Sulfadimethoxine & $<0.005$ & 0 \\
Sulfamerazine & $<0.005$ & 0 \\
Sulfamethazine & $<0.005$ & 1 \\
Sulfamethoxazole & $<0.005$ & 16 \\
Sulfathiazole & $<0.005$ & 0 \\
\hline
\end{tabular}

\begin{tabular}{lcl}
\hline \multicolumn{1}{c}{ Constituent } & $\begin{array}{c}\text { Detection } \\
\text { level }\end{array}$ & $\begin{array}{c}\text { Number of } \\
\text { detections }\end{array}$ \\
\hline \multicolumn{1}{c}{ Tetracyclines and degradation products } \\
\hline Chlorotetracycline & $<0.010$ & 0 \\
Anhydro-Chlorotetracycline & $<0.010$ & 0 \\
Epi-anhydro-Chlorotetracycline & $<0.010$ & 0 \\
Epi-chlorotetracycline & $<0.010$ & 0 \\
Epi-iso-Chlorotetracycline & $<0.010$ & 0 \\
Iso-Chlorotetracycline & $<0.010$ & 1 \\
Demeclocycline & $<0.010$ & 0 \\
Doxycycline & $<0.010$ & 0 \\
Minocycline & $<0.010$ & 0 \\
Oxytetracycline & $<0.010$ & 0 \\
Alpha apo-oxytetracycline & $<0.010$ & 0 \\
Beta apo-oxytetracycline & $<0.010$ & 0 \\
Epi-oxytetracycline & $<0.010$ & 0 \\
Tetracycline & $<0.010$ & 0 \\
Anhydro-tetracycline & $<0.010$ & 0 \\
Epi-anhydro-tetracycline & $<0.010$ & 0 \\
Epi-tetracycline & $<0.010$ & 0 \\
\hline Carbadox & $<0.005$ & 0 \\
\hline Ormetoprim & & 0 \\
\hline
\end{tabular}




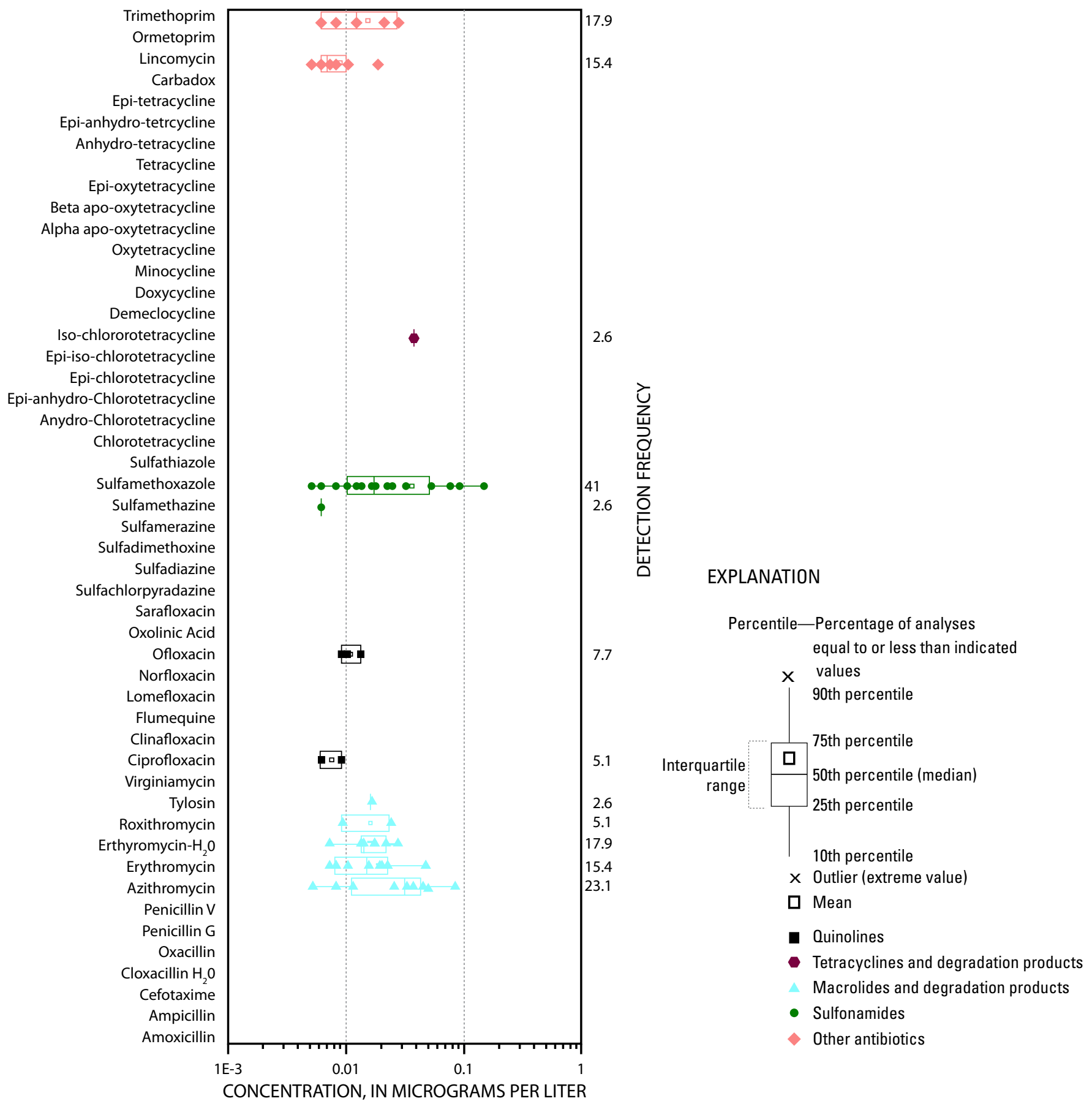

Figure 4. Occurrence and concentrations of antibiotic compounds at sites in the upper Scioto River Basin, Ohio, and corresponding detection frequencies evaluated against each compound's miminum reporting level. 
Figure 5. Total number of detections (61) by antibiotic group for collection sites in the upper Scioto River Basin, 2005-6 ( $n$, number of detections; beta lactams were not detected).
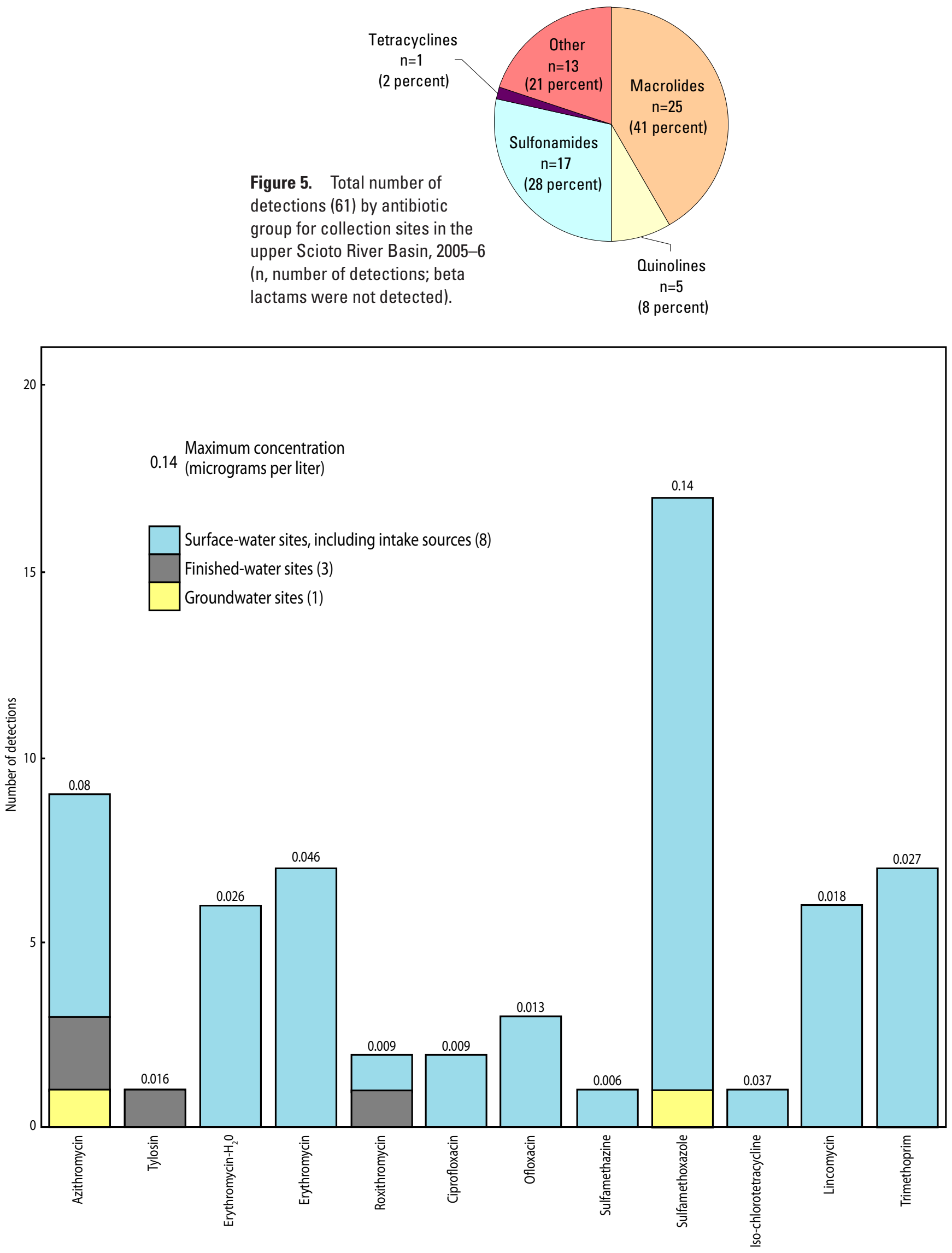

Figure 6. Summary of antibiotic compounds detected in water samples collected from the upper Scioto River Basin, 0hio, 2005-6. 


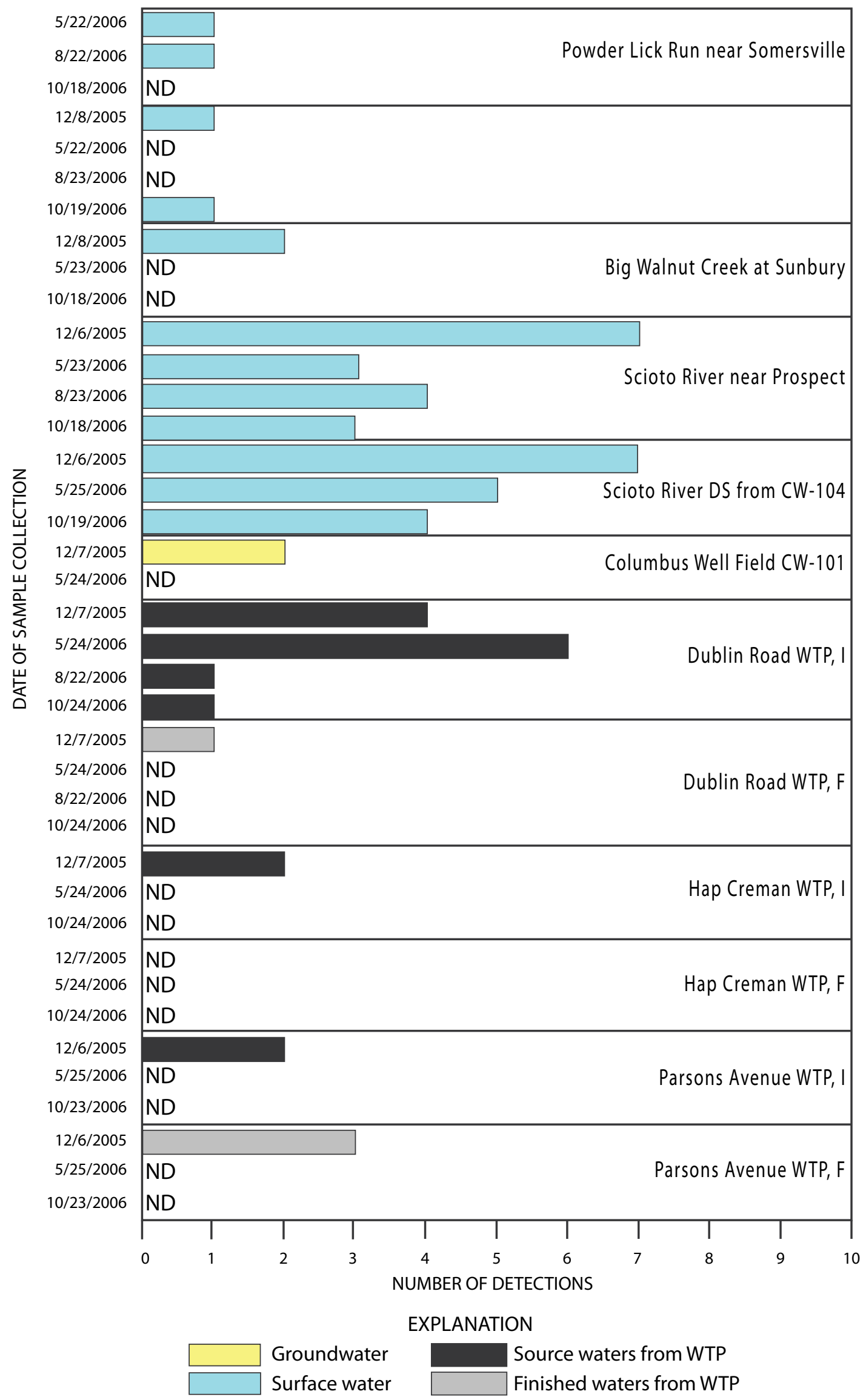

Figure 7. Numbers of detections of antibiotic compounds by sampling site and date in source and finished waters of the upper Scioto River Basin, central Ohio, 2005-6. 


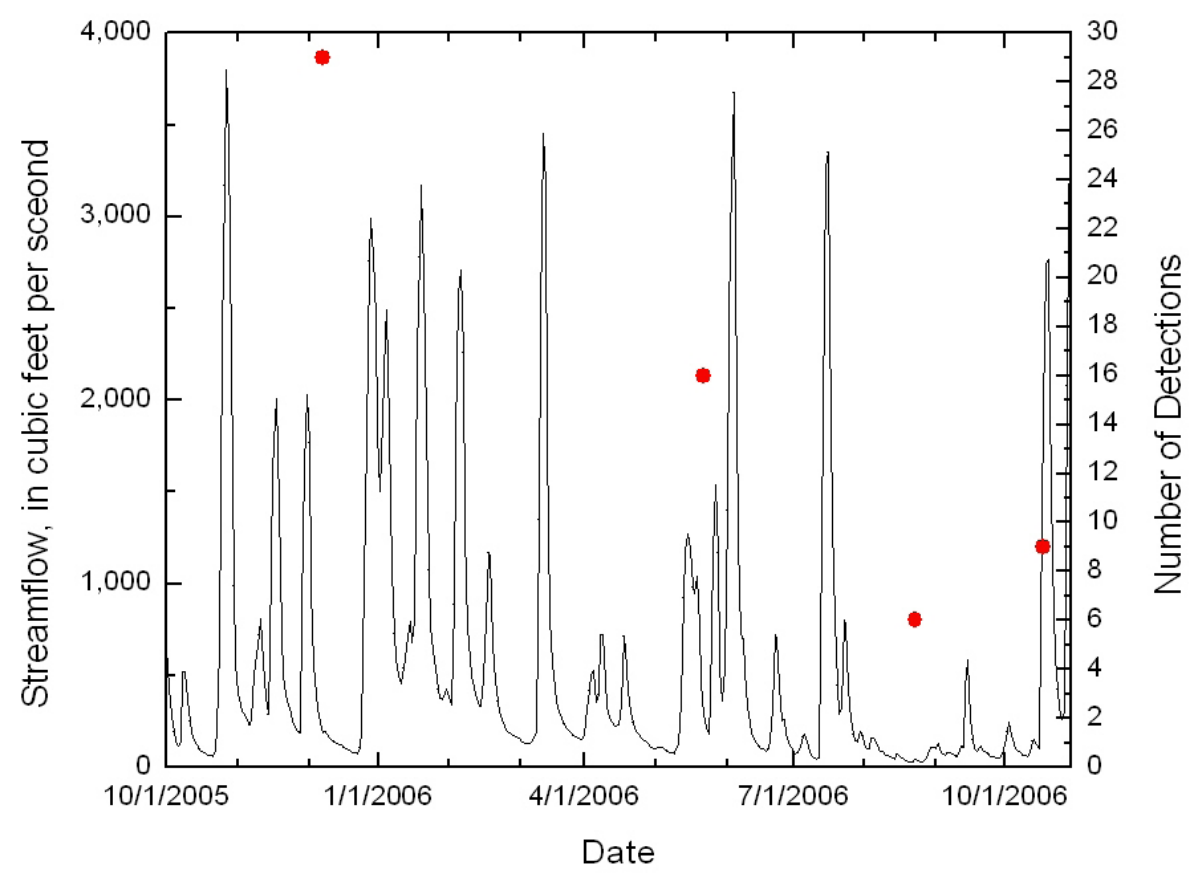

Scioto River near Prospect, Ohio

\section{EXPLANATION}

\section{_ Daily mean streamflow \\ - Number of detections}

Figure 8. Total number of detections at all sites, by season, in the upper Scioto River Basin, central Ohio, 2005-6.

Comparing results from the previous study to those from this study, the antibiotic analysis method used during 2001 included just over half (26) of the antibiotic compounds tested for in 2005-6 (49). In addition, four of the compounds analyzed for in 2001 were not analyzed for in 2005-6, and the minimum reporting limits (MRLs) ranged from twice to an order of magnitude higher than the current laboratory MRLs. Not surprisingly, many of the compounds detected in the earlier investigations were the same as those detected in this report (fig. 1). It is important to note that the number of antibiotic compounds reported in 2001 (3) was far fewer than the compounds reported in 2005-6 (61). It is expected that lower MRLs and an expanded compound analysis list, such as the ones used in this study, would yield higher detection frequencies. 


\section{Summary and Conclusions}

Occurrence of antibiotic compounds in surface-andgroundwater has been a topic of increasing interest, along with the understanding of fate (or transport) of these compounds and the possible health effects in humans and aquatic life. The U.S. Geological Survey, in cooperation with the City of Columbus, Division of Power and Water, collected water samples from locations in the upper Scioto River Basin from December 2005 to October 2006 to determine the occurrence and distribution of antibiotic compounds in source water from the City of Columbus, Ohio. Samples were collected from five surface-water sites, one groundwater site, and two sites - a source- and finished-water site - at each of three water-treatment plants (WTPs). In an effort to target worstcase conditions, samples were collected during periods when results of daily nitrate and pesticide monitoring done by the Columbus Division of Power and Water indicated that concentrations of agrochemicals were highest in the source water. Low-flow samples were collected in late summer in an effort to target periods when treated wastewater and septic-tank discharge likely represent a larger proportion of the total streamflow. The quality-control (QC) procedures, which consisted of collecting and analyzing field blanks and replicates, followed a general quality-assurance/quality control protocol established for low-level organic analyses. Antibiotic field blank samples represented about 15 percent of the environmental samples and yielded no detections. Two replicate samples were collected at study sites Columbus Well Field CW-101 and Powder Lick Run near Summersville, Ohio. The replicates indicated good reproducibility of laboratory results with an identical concentration of $(0.005 \mu \mathrm{g} / \mathrm{L})$ for lincomycin.

Of the 49 targeted antibiotic compounds, 12 (24 percent) were detected at least one time for a total of 61 detections. These compounds were trimethoprim, lincomycin, iso-chlorotetracycline, sulfamethoxazole, sulfamethazine, ofloxacin, ciprofloxacin, tylosin, roxithromycin, erythromycin- $\mathrm{H}_{2} \mathrm{O}$, erythromycin, and azithromycin. Sulfamethoxazole, an antibiotic compound that is often used in combination with other antibiotics to treat infections, had the single highest concentration at $0.14 \mu \mathrm{g} / \mathrm{L}$. Azithromycin ( 9 detections) was most frequently detected macrolide and sulfamethoxazole (16 detections) was the most commonly detected sulfonamide. At least one antibiotic was detected at 11 of the 12 sites; Hap Cremean F was the only site with no antibiotic detections. Scioto River near Prospect had the most detections overall at 17 and the most detections (7) on any one sampling date (on December 8, 2005). The Scioto River downstream from CW-104 had a total of 16 detections. Data from surface-water sites were evaluated to determine potential seasonal variations in occurrence and concentrations. The number of antibiotic detections decreased from winter (31) to summer (6) and rose slightly in the fall (9). The winter sample (December 2005) yielded just over 50 percent of the total detections for this investigation in a relatively low-flow setting.
Throughout the duration of this project, knowledge of collection, processing, and analysis of organic wastewater contaminants have continued to evolve and improve. Timeintegrated source and finished-water samples collected over a 24-hour period with calculated residence time between the source and finished would be a preferred collection method compared to a grab sample for water-treatment plants. Allowing for residence time in the treatment process would provide a more thorough evaluation of occurrence and distribution and would also improve understanding of drinking-water treatment processes and persistence of measurable concentrations of organic wastewater contaminants in finished water.

\section{References Cited}

Boyd, R.A., and Furlong, E.T., 2002, Human-health pharmaceutical compounds in Lake Mead, Nevada and Arizona, and Las Vegas Wash, Nevada, October 2000-August 2001: U.S. Geological Survey Open-File Report 02-385, 18 p.

Casewell, Mark; Friis, Christian; Marco, Enrico; McMullin, Paul; and Phillips, Ian, 2003, The European ban on growthpromoting antibiotics and emerging consequences for human and animal health: Journal of Antimicrobial Chemotherapy, v. 52 , no. 2 , p. $159-161$.

Cižman, Milan; Pokorn, Marko; Seme, Katja; Oražem, Andreja; and Paragi, Metka, 2001, The relationship between trends in macrolide use and resistance to macrolides of common respiratory pathogens: Journal of Antimicrobial Chemotherapy, v. 47, no. 4, p. 475-477.

Columbus Department of Public Utilities, Water Sources: Accessed October 7, 2009, at http://utilities.columbus.gov/ Water/WaterSources\%20.htm.

Halling-Sørensen, B.; Nielson, S.N.; Lanzky, P.F.; Ingerslev, F.; Holten Lützhoft, H.C.; and Jorgensen, S.E., 1998, Occurrence, fate and effects of pharmaceutical substances in the environment-A review: Chemosphere, v. 35, no. 2, p. 357-393.

Hooper, D.C., 1998, Expanding uses of fluoroquinolonesOpportunities and challenges: Annals of Internal Medicine, v. 129 , no. 11 , pt. 1 , p. $908-910$.

Huang, C.H., Renew, J.E., Smeby, K.L., Pinkston, K., and Sedlak, D.L., 2001, Assessment of potential antibiotic contaminants in water and preliminary occurrence analysis, in Second International Conference on Pharmaceuticals and Endocrine Disrupting Chemicals in Water, October 9-11, 2001, Minneapolis, Minn.: National Ground Water Association. 
Galloway, J.M., Haggard, B.E., Meyers, M.T., and Green, W.R., 2005, Occurrence of pharmaceuticals and other organic wastewater constituents in selected streams in northern Arkansas, 2004: U.S. Geological Survey Scientific Investigations Report 2005-5140, 24 p.

Kolpin, D.W., Furlong, E.T., Meyer, M.T., Thurman, E.M., Zaugg, S.D., Barber, L.B., and Buxton, H.T., 2002, Pharmaceuticals, hormones, and other organic wastewater contaminants in U.S. streams, 1999-2000-A national reconnaissance: Environmental Science \& Technology, v. 36, no. 6, p. 1202-1211.

Lipsitch, Marc; Singer, R.S.; and Levin, B.R., 2002, Antibiotics in agriculture-When is it time to close the barn door?: Proceedings of the National Academy of Sciences, v. 99, no. 9 , p. 5752-5754.

Meyer, M.T., Lee, E.A., Ferrell, G.M., Bumgarner, J.E., and Varns, Jerry, 2007, Evaluation of offline tandem and online solid-phase extraction with liquid chromatography/electrospray ionization-mass spectrometry for analysis of antibiotics in ambient water and comparison to an independent method: U.S. Geological Survey Scientific Investigations Report 2007-5021, 28 p.

Mueller, D.K., Martin, J.D., and Lopes, T.J., 1997, Qualitycontrol design for surface-water sampling in the National Water-Quality Assessment Program: U.S. Geological Survey Open-File Report 97-223, p. 3-6.

Nature Conservancy, 2007, Lower Scioto River BasinBuilding partnerships to sustain high-quality waters: Accessed September 26, 2007, at http://www.nature.org/ wherewework/northamerica/states/ohio/preserves/art16099. html.

Oblinger, C.J., Sheets, R.A., and Bair, E.S., 1991, Hydrology and water quality near the South Well Field, southern Franklin County, Ohio, with emphasis on the simulation of ground-water flow and transport of Scioto River: U.S. Geological Survey Water-Resources Investigations Report 91-4080, 78 p.
Resources First Foundation, 2007, Ohio Scioto River Basin Conservation Reserve Enhancement Program-Buffers and wetlands improving water quality: Accessed September 26, 2007, at http://www.cooperativeconservationamerica.org/ viewproject.asp?pid $=535$.

Rowe, G.L., Jr., Reutter, D.C., Runkle, D.L., Hambrook, J.A., Janosy, S.D., and Hwang, L.H., 2004, Water quality in the Great and Little Miami River Basins: U.S. Geological Survey Circular 1229, p. 23-25.

Scholar, E.M., 2003, Fluoroquinolines-Past, present, and future of a novel group of antibacterial agents: American Journal of Pharmaceutical Education, v. 66, p. 164-172.

Smilack, J.D., 1999, Symposium on antimicrobial agentsThe tetracyclines: Mayo Clinic Proceedings, v. 74, p. $727-729$.

Stratton, L., 2002, Afraid of the water: Columbus (Ohio) Dispatch, March 24, 2002, Home and Garden section.

U.S. Geological Survey, 2007, Toxic Substances Hydrology Program: Accessed September 26, 2007, at http://toxics. usgs.gov/regional/emc/index.html.

Wilde, F.D.; Radtke, D.B.; Gibs, Jacob; and Iwatsubo, R.T., 2004, Processing of water samples, version 2.1: U.S. Geological Survey Techniques of Water-Resources Investigations, book 9, chap. A5, accessed October 2007 at http://pubs.water.usgs.gov/twri9A5/.

Wilde, F.D.; Radtke, D.B.; Gibs, Jacob; and Iwatsubo, R.T., 2006, Collection of water samples, version 2.0: U.S. Geological Survey Techniques of Water-Resources Investigations, book 9, chap. A4, accessed October 2007 at http://pubs.water.usgs.gov/twri9A4/. 


\section{Appendixes 1-2}

Appendix 1. Water-Quality Analyses and Quality-Control Tests

Appendix 2. Sample Analysis 


\section{Appendix 1. Water-Quality Analyses and Quality-Control Results}

Table 1-1. Field parameters from sampling locations in the upper Scioto River Basin, Ohio, 2005-6.

$\left[\mathrm{ft}^{3} / \mathrm{s}\right.$, cubic feet per second; $\mu \mathrm{S} / \mathrm{cm}$, microsiemens per centimeter at 25 degrees Celsius; $\mathrm{mg} / \mathrm{L}$, milligrams per liter; ${ }^{\circ} \mathrm{C}$, degrees Celsius; mm Hg, millimeters of mercury; - , not measured; <, less than; WTP, water-treatment plant; DS, downstream; CW, collector well; F, finished water; I, intake]

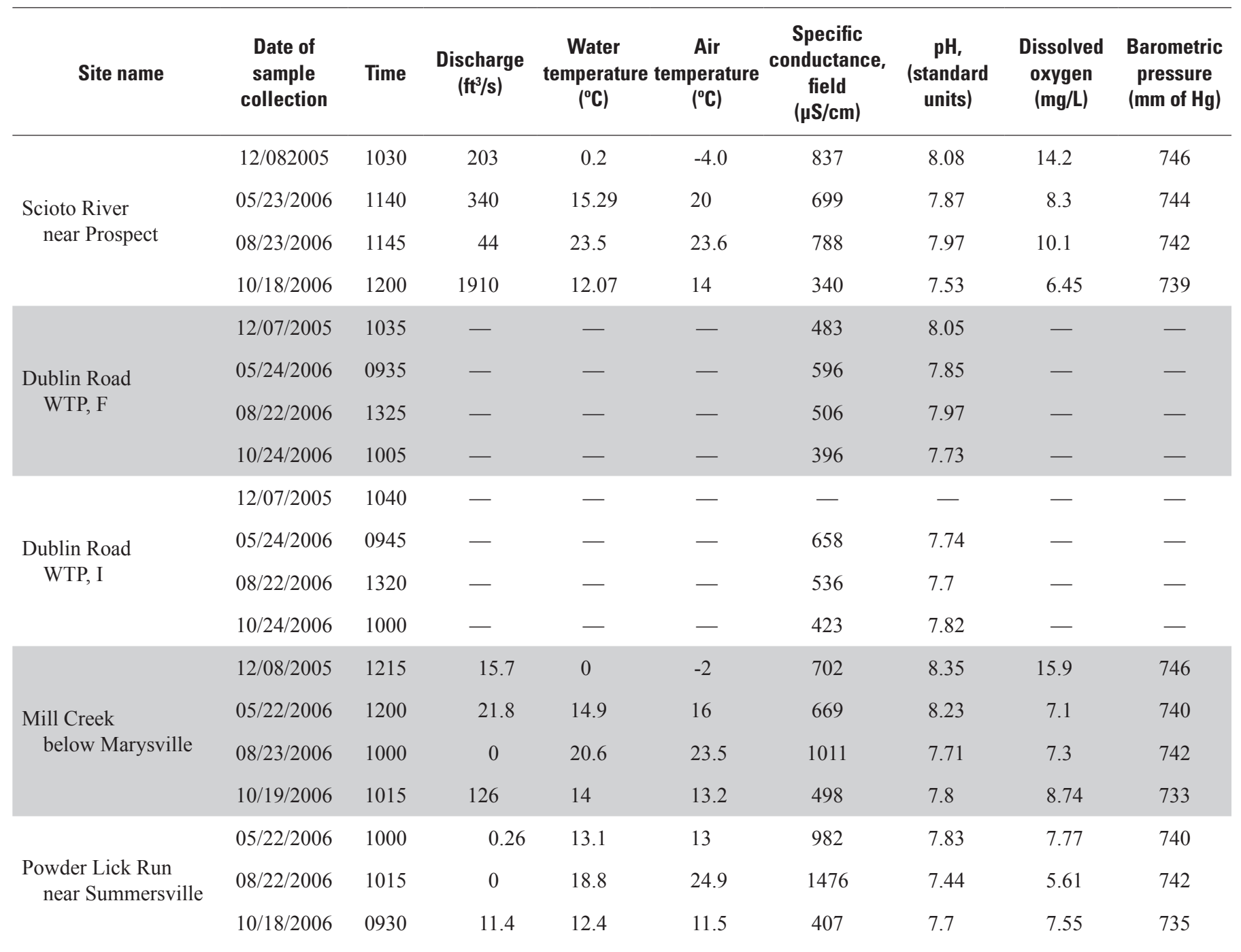


Table 1-1. Field parameters from sampling locations in the upper Scioto River Basin, Ohio, 2005-6.-Continued

$\left[\mathrm{ft}^{3} / \mathrm{s}\right.$, cubic feet per second; $\mu \mathrm{S} / \mathrm{cm}$, microsiemens per centimeter at 25 degrees Celsius; $\mathrm{mg} / \mathrm{L}$, milligrams per liter; ${ }^{\circ} \mathrm{C}$, degrees Celsius; $\mathrm{mm}$ Hg, millimeters of mercury; - , not measured; <, less than; WTP, water-treatment plant; DS, downstream; CW, collector well; F, finished water; I, intake]

\begin{tabular}{|c|c|c|c|c|c|c|c|c|c|}
\hline Site name & $\begin{array}{l}\text { Date of } \\
\text { sample } \\
\text { collection }\end{array}$ & Time & $\begin{array}{c}\text { Discharge } \\
\left(\mathrm{ft}^{3} / \mathrm{s}\right)\end{array}$ & $\begin{array}{l}\text { Water } \\
\text { temperature } \\
\left.\quad{ }^{\circ} \mathrm{C}\right)\end{array}$ & $\begin{array}{l}\text { Air } \\
\text { temperature } \\
\left.\text { ( }{ }^{\circ} \mathrm{C}\right)\end{array}$ & $\begin{array}{c}\text { Specific } \\
\text { conductance, } \\
\text { field } \\
(\mu \mathrm{S} / \mathrm{cm})\end{array}$ & $\begin{array}{c}\mathrm{pH}, \\
\text { (standard } \\
\text { units) }\end{array}$ & $\begin{array}{l}\text { Dissolved } \\
\text { oxygen } \\
\text { (mg/L) }\end{array}$ & $\begin{array}{l}\text { Barometric } \\
\text { pressure } \\
(\mathrm{mm} \text { of } \mathrm{Hg})\end{array}$ \\
\hline \multirow{3}{*}{$\begin{array}{l}\text { Hap Cremean } \\
\text { WTP, I }\end{array}$} & $12 / 07 / 2005$ & 1120 & - & - & - & 384 & 8.1 & - & - \\
\hline & $05 / 24 / 2006$ & 1010 & - & - & - & 410 & 7.89 & - & - \\
\hline & $10 / 24 / 2006$ & 1035 & - & - & - & 379 & 8.33 & - & - \\
\hline \multirow{3}{*}{$\begin{array}{l}\text { Hap Cremean } \\
\text { WTP, F }\end{array}$} & $12 / 07 / 2005$ & 1115 & - & - & - & 340 & 8.14 & - & - \\
\hline & $05 / 24 / 2006$ & 1015 & - & - & - & 322 & 7.38 & - & - \\
\hline & $10 / 24 / 2006$ & 1040 & - & - & - & 329 & 8.11 & - & - \\
\hline \multirow{3}{*}{$\begin{array}{l}\text { Scioto River } \\
\text { DS from CW-104 }\end{array}$} & $12 / 06 / 2005$ & 1130 & 1840 & 7.3 & -3.0 & 671 & 8.1 & - & 745 \\
\hline & $05 / 23 / 2006$ & 1400 & 1370 & 17.1 & 23 & 706 & 8.2 & 10.2 & 752 \\
\hline & $10 / 19 / 2006$ & 1315 & 7460 & 13.82 & 16 & 608 & 7.87 & 9.93 & 740 \\
\hline \multirow{3}{*}{$\begin{array}{l}\text { Big Walnut Creek } \\
\text { at Sunbury }\end{array}$} & $12 / 08 / 2005$ & 0915 & 25 & 0 & -9.0 & 701 & 8.27 & 15.8 & 746 \\
\hline & $05 / 23 / 2006$ & 1000 & 49 & 12.3 & 14 & 529 & 8.22 & 10.61 & 744 \\
\hline & $10 / 18 / 2006$ & 1330 & 447 & 13.11 & 17.5 & 363 & 7.75 & 9.98 & 739 \\
\hline \multirow{2}{*}{$\begin{array}{l}\text { Columbus Well Field } \\
\text { CW-101 }\end{array}$} & $12 / 06 / 2005$ & 1055 & - & - & - & 781 & 7.5 & - & - \\
\hline & $05 / 25 / 2006$ & 1010 & - & - & - & 829 & 7.3 & - & - \\
\hline \multirow{3}{*}{$\begin{array}{l}\text { Parsons Avenue } \\
\text { WTP, I }\end{array}$} & $12 / 06 / 2005$ & 1020 & - & - & - & 867 & 7.24 & - & - \\
\hline & $05 / 25 / 2006$ & 0940 & - & - & - & 861 & 7.09 & - & - \\
\hline & $10 / 23 / 2006$ & 1310 & - & - & - & 882 & 7.5 & - & - \\
\hline \multirow{3}{*}{$\begin{array}{l}\text { Parsons Avenue } \\
\text { WTP, F }\end{array}$} & $12 / 06 / 2005$ & 1015 & - & - & - & 560 & 7.8 & - & - \\
\hline & $05 / 23 / 2006$ & 0945 & - & - & - & 554 & 7.46 & - & - \\
\hline & $10 / 23 / 2006$ & 1315 & - & - & - & 536 & 7.7 & - & - \\
\hline
\end{tabular}


Table 1-2. Water-quality analyses from sampling locations in the upper Scioto River Basin, Ohio, 2005-6.

[ $\mu \mathrm{g} / \mathrm{L}$, micrograms per liter; <, less than; WTP, water-treatment plant; F, finished water; I, intake; CW, collector well; DS, downstream; bold, value exceeded detection or reporting level]

\begin{tabular}{|c|c|c|c|c|c|c|c|c|c|}
\hline Site name & Date & Time & Lincomycin & Carbadox & Trimethoprim & Ormetoprim & Tetracycline & $\begin{array}{c}\text { Anhydro- } \\
\text { tetracycline }\end{array}$ & $\begin{array}{c}\text { Epi- } \\
\text { tetracycline }\end{array}$ \\
\hline \multirow{3}{*}{$\begin{array}{l}\text { Scioto River } \\
\text { near Prospect }\end{array}$} & $12 / 08 / 2005$ & 1030 & $<0.005$ & $<0.005$ & 0.012 & $<0.005$ & $<0.010$ & $<0.010$ & $<0.010$ \\
\hline & $05 / 23 / 2006$ & 1140 & $<0.005$ & $<0.005$ & 0.006 & $<0.005$ & $<0.010$ & $<0.010$ & $<0.010$ \\
\hline & $08 / 23 / 2006$ & 1145 & $<0.005$ & $<0.005$ & 0.006 & $<0.005$ & $<0.010$ & $<0.010$ & $<0.010$ \\
\hline \multirow{4}{*}{$\begin{array}{l}\text { Dublin Road } \\
\text { WTP, F }\end{array}$} & $12 / 07 / 2005$ & 1035 & $<0.005$ & $<0.005$ & $<0.005$ & $<0.005$ & $<0.010$ & $<0.010$ & $<0.010$ \\
\hline & $05 / 24 / 2006$ & 0935 & $<0.005$ & $<0.005$ & $<0.005$ & $<0.005$ & $<0.010$ & $<0.010$ & $<0.010$ \\
\hline & $08 / 22 / 2006$ & 1325 & $<0.005$ & $<0.005$ & $<0.005$ & $<0.005$ & $<0.010$ & $<0.010$ & $<0.010$ \\
\hline & $10 / 24 / 2006$ & 1005 & $<0.005$ & $<0.005$ & $<0.005$ & $<0.005$ & $<0.010$ & $<0.010$ & $<0.010$ \\
\hline $\begin{array}{l}\text { Dublin Road } \\
\text { WTP, I }\end{array}$ & $10 / 24 / 2006$ & 1000 & $<0.005$ & $<0.005$ & $<0.005$ & $<0.005$ & $<0.010$ & $<0.010$ & $<0.010$ \\
\hline \multirow{4}{*}{$\begin{array}{l}\text { Mill Creek } \\
\text { below Marysville }\end{array}$} & $12 / 08 / 2005$ & 1215 & $<0.005$ & $<0.005$ & $<0.005$ & $<0.005$ & $<0.010$ & $<0.010$ & $<0.010$ \\
\hline & $05 / 22 / 2006$ & 1200 & $<0.005$ & $<0.005$ & $<0.005$ & $<0.005$ & $<0.010$ & $<0.010$ & $<0.010$ \\
\hline & $08 / 23 / 2006$ & 1000 & $<0.005$ & $<0.005$ & $<0.005$ & $<0.005$ & $<0.010$ & $<0.010$ & $<0.010$ \\
\hline & $10 / 19 / 2006$ & 1015 & 0.010 & $<0.005$ & $<0.005$ & $<0.005$ & $<0.010$ & $<0.010$ & $<0.010$ \\
\hline \multirow[b]{2}{*}{$\begin{array}{l}\text { Powder Lick Run } \\
\text { near Summersville }\end{array}$} & $05 / 22 / 2006$ & 1000 & 0.005 & $<0.005$ & $<0.005$ & $<0.005$ & $<0.010$ & $<0.010$ & $<0.010$ \\
\hline & $08 / 22 / 2006$ & 1015 & 0.008 & $<0.005$ & $<0.005$ & $<0.005$ & $<0.010$ & $<0.010$ & $<0.010$ \\
\hline
\end{tabular}


Table 1-2. Water-quality analyses from sampling locations in the upper Scioto River Basin, Ohio, 2005-6.-Continued

$[\mu \mathrm{g} / \mathrm{L}$, micrograms per liter; <, less than; WTP, water-treatment plant; F, finished water; I, intake; CW, collector well; DS, downstream; bold, value exceeded detection or reporting level]

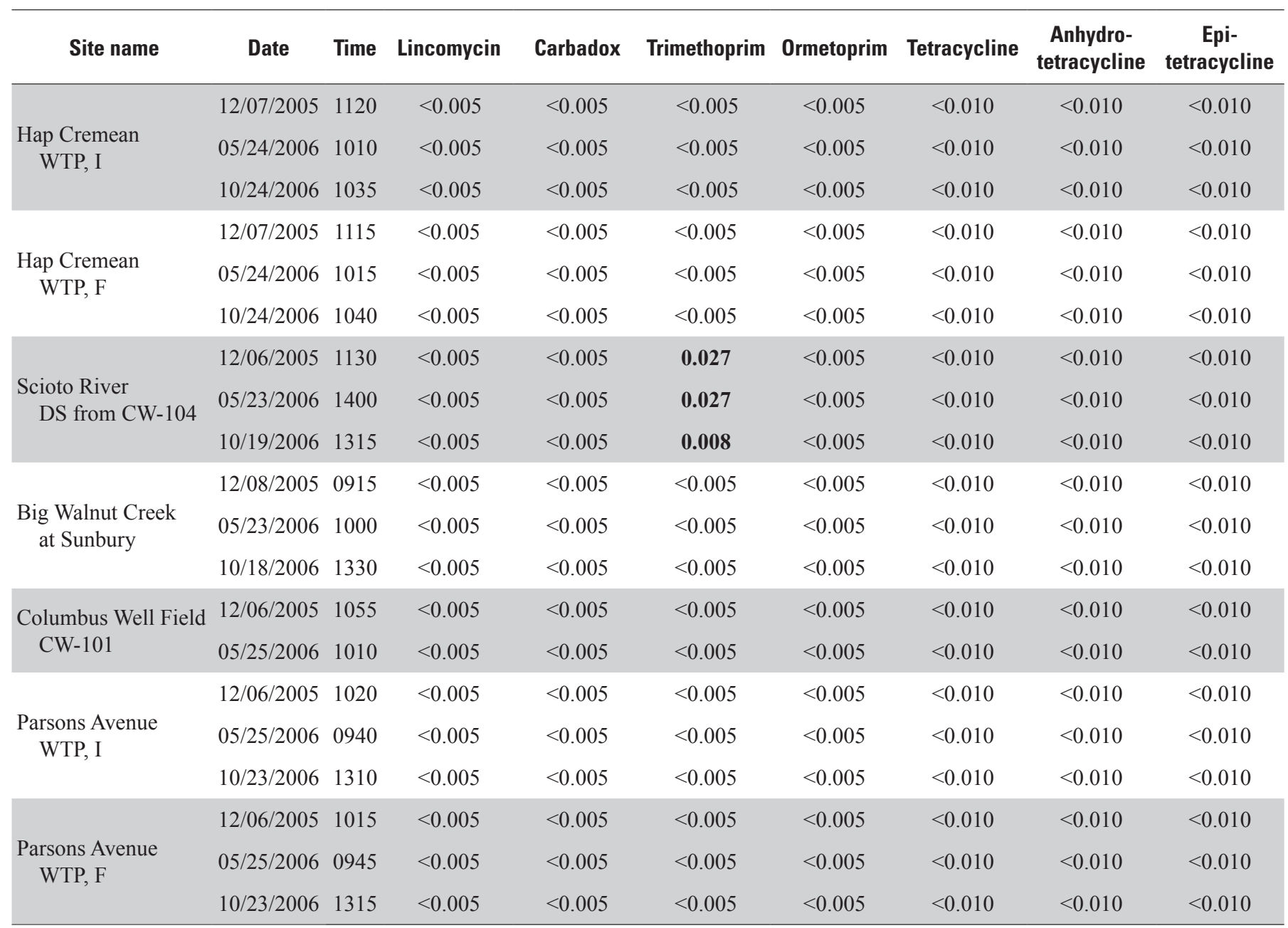




\section{Antibiotic Compounds in Source Water and Finished Drinking Water, Upper Scioto River Basin, Ohio, 2005-6}

Table 1-2. Water-quality analyses from sampling locations in the upper Scioto River Basin, Ohio, 2005-6.-Continued

$[\mu \mathrm{g} / \mathrm{L}$, micrograms per liter; <, less than; WTP, water-treatment plant; F, finished water; I, intake; CW, collector well; DS, downstream; bold, value exceeded detection or reporting level]

\begin{tabular}{|c|c|c|c|c|c|c|c|c|c|}
\hline Site name & Date & Time & $\begin{array}{c}\text { Epi- } \\
\text { anhydro- } \\
\text { tetracycline }\end{array}$ & $\begin{array}{c}\text { Chloro- } \\
\text { tetracycline }\end{array}$ & $\begin{array}{c}\text { Anhydro- } \\
\text { chloro- } \\
\text { tetracycline }\end{array}$ & $\begin{array}{c}\text { Epi- } \\
\text { anhydro- } \\
\text { chloro- } \\
\text { tetracycline }\end{array}$ & $\begin{array}{l}\text { Epichloro- } \\
\text { tetracycline }\end{array}$ & $\begin{array}{l}\text { Isochloro- } \\
\text { tetracycline }\end{array}$ & $\begin{array}{c}\text { Epi- } \\
\text { isochloro- } \\
\text { tetracycline }\end{array}$ \\
\hline \multirow{3}{*}{$\begin{array}{l}\text { Scioto River } \\
\text { near Prospect }\end{array}$} & $12 / 08 / 2005$ & 1030 & $<0.010$ & $<0.010$ & $<0.010$ & $<0.010$ & $<0.010$ & $<0.010$ & $<0.010$ \\
\hline & $05 / 23 / 2006$ & 1140 & $<0.010$ & $<0.010$ & $<0.010$ & $<0.010$ & $<0.010$ & $<0.010$ & $<0.010$ \\
\hline & $10 / 18 / 2006$ & 1200 & $<0.010$ & $<0.010$ & $<0.010$ & $<0.010$ & $<0.010$ & 0.037 & $<0.010$ \\
\hline \multirow{2}{*}{$\begin{array}{c}\text { Dublin Road } \\
\text { WTP, F }\end{array}$} & $12 / 07 / 2005$ & 1035 & $<0.010$ & $<0.010$ & $<0.010$ & $<0.010$ & $<0.010$ & $<0.010$ & $<0.010$ \\
\hline & $05 / 24 / 2006$ & 0935 & $<0.010$ & $<0.010$ & $<0.010$ & $<0.010$ & $<0.010$ & $<0.010$ & $<0.010$ \\
\hline \multirow{3}{*}{$\begin{array}{l}\text { Dublin Road } \\
\text { WTP, I }\end{array}$} & $05 / 24 / 2006$ & 0945 & $<0.010$ & $<0.010$ & $<0.010$ & $<0.010$ & $<0.010$ & $<0.010$ & $<0.010$ \\
\hline & $08 / 22 / 2006$ & 1320 & $<0.010$ & $<0.010$ & $<0.010$ & $<0.010$ & $<0.010$ & $<0.010$ & $<0.010$ \\
\hline & $10 / 24 / 2006$ & 1000 & $<0.010$ & $<0.010$ & $<0.010$ & $<0.010$ & $<0.010$ & $<0.010$ & $<0.010$ \\
\hline \multirow{4}{*}{$\begin{array}{l}\text { Mill Creek } \\
\text { below Marysville }\end{array}$} & $12 / 08 / 2005$ & 1215 & $<0.010$ & $<0.010$ & $<0.010$ & $<0.010$ & $<0.010$ & $<0.010$ & $<0.010$ \\
\hline & $05 / 22 / 2006$ & 1200 & $<0.010$ & $<0.010$ & $<0.010$ & $<0.010$ & $<0.010$ & $<0.010$ & $<0.010$ \\
\hline & $08 / 23 / 2006$ & 1000 & $<0.010$ & $<0.010$ & $<0.010$ & $<0.010$ & $<0.010$ & $<0.010$ & $<0.010$ \\
\hline & $10 / 19 / 2006$ & 1015 & $<0.010$ & $<0.010$ & $<0.010$ & $<0.010$ & $<0.010$ & $<0.010$ & $<0.010$ \\
\hline
\end{tabular}


Table 1-2. Water-quality analyses from sampling locations in the upper Scioto River Basin, Ohio, 2005-6.-Continued

$[\mu \mathrm{g} / \mathrm{L}$, micrograms per liter; <, less than; WTP, water-treatment plant; F, finished water; I, intake; CW, collector well; DS, downstream; bold, value exceeded detection or reporting level]

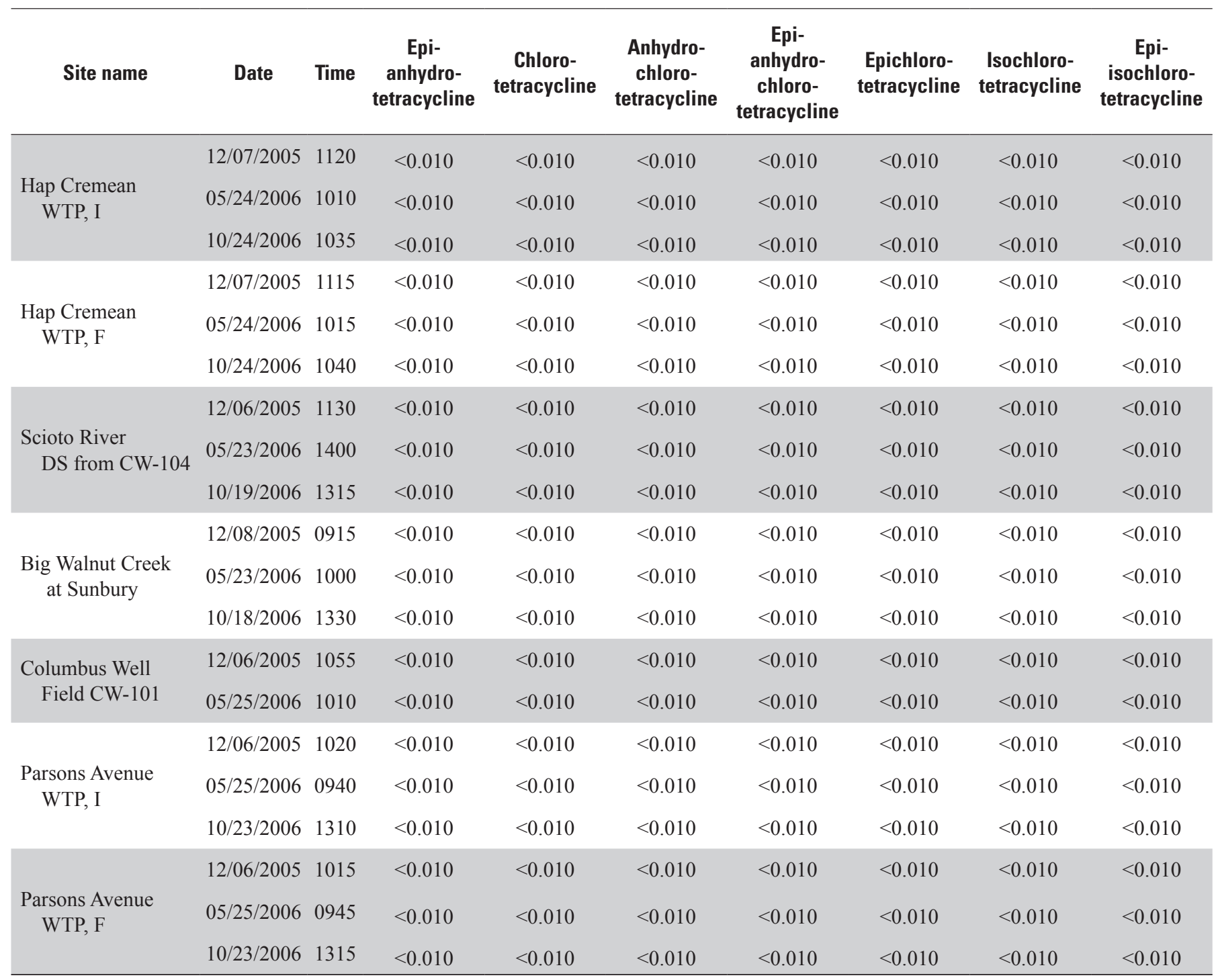


24 Antibiotic Compounds in Source Water and Finished Drinking Water, Upper Scioto River Basin, Ohio, 2005-6

Table 1-2. Water-quality analyses from sampling locations in the upper Scioto River Basin, Ohio, 2005-6.-Continued

$[\mu \mathrm{g} / \mathrm{L}$, micrograms per liter; $<$, less than; WTP, water-treatment plant; F, finished water; I, intake; CW, collector well; DS, downstream; bold, value exceeded detection or reporting level]

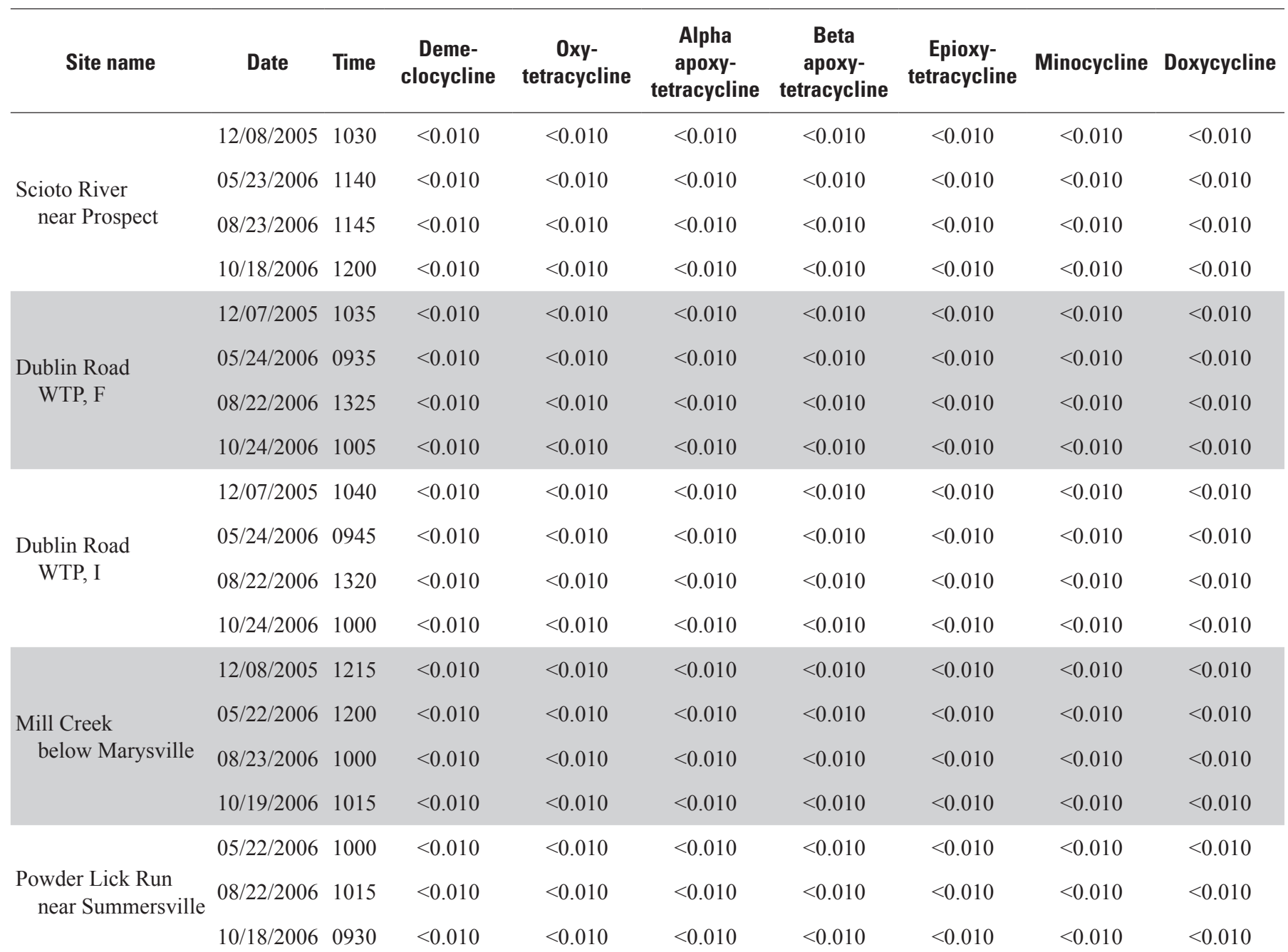


Table 1-2. Water-quality analyses from sampling locations in the upper Scioto River Basin, 0hio, 2005-6.-Continued

$[\mu \mathrm{g} / \mathrm{L}$, micrograms per liter; <, less than; WTP, water-treatment plant; F, finished water; I, intake; CW, collector well; DS, downstream; bold, value exceeded detection or reporting level]

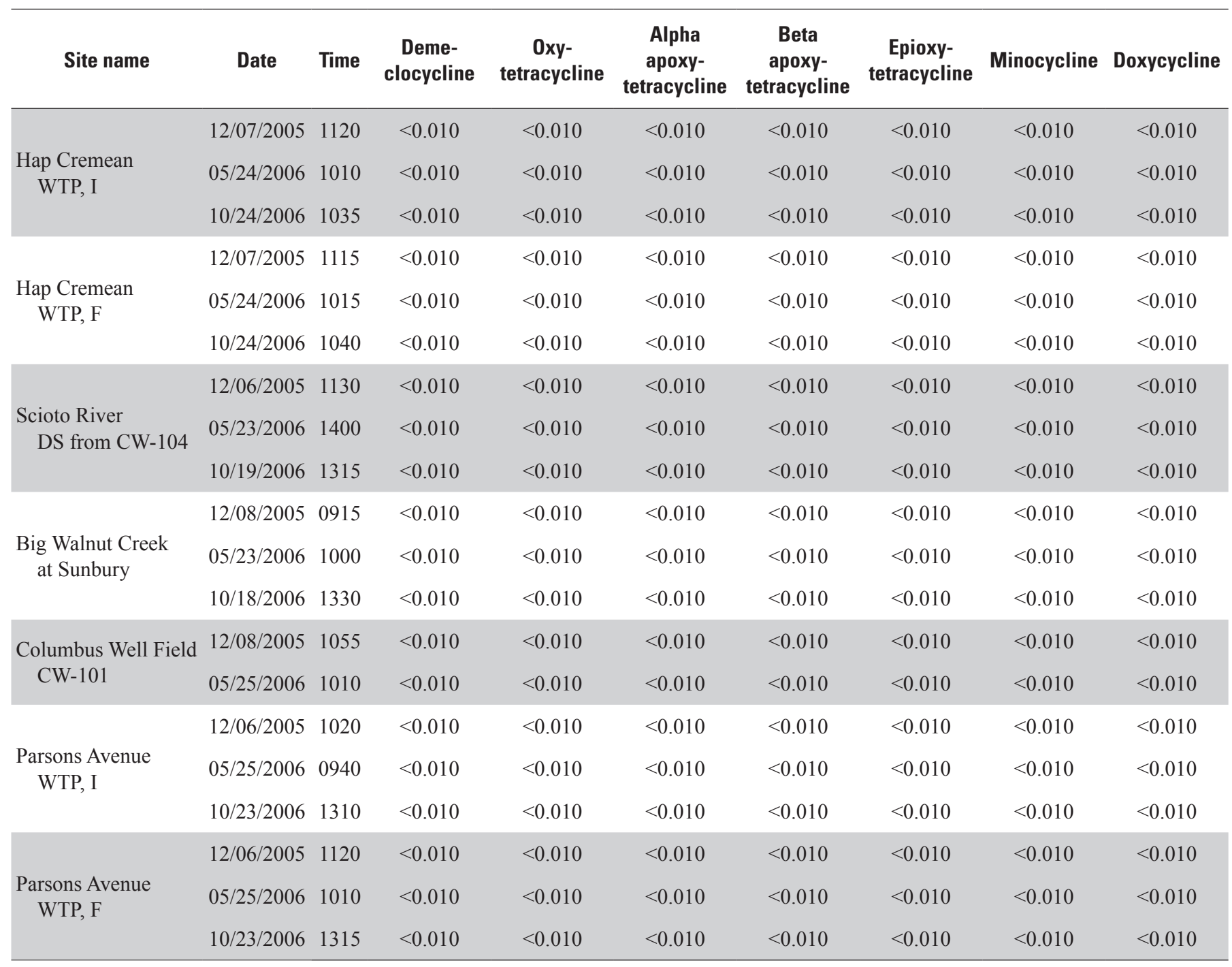


26 Antibiotic Compounds in Source Water and Finished Drinking Water, Upper Scioto River Basin, Ohio, 2005-6

Table 1-2. Water-quality analyses from sampling locations in the upper Scioto River Basin, Ohio, 2005-6.-Continued

$[\mu \mathrm{g} / \mathrm{L}$, micrograms per liter; <, less than; WTP, water-treatment plant; F, finished water; I, intake; CW, collector well; DS, downstream; bold, value exceeded detection or reporting level]

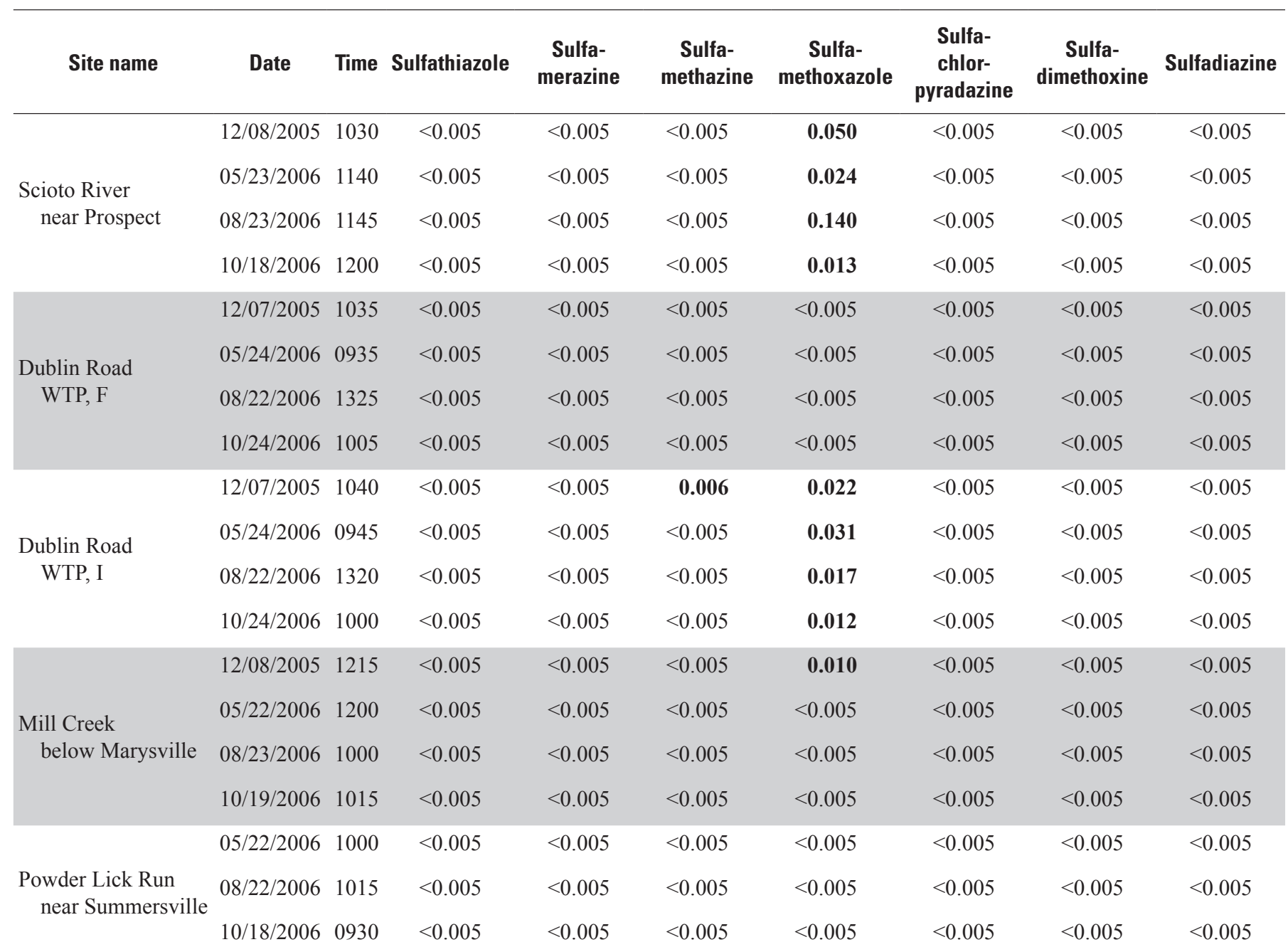


Table 1-2. Water-quality analyses from sampling locations in the upper Scioto River Basin, Ohio, 2005-6.-Continued

$[\mu \mathrm{g} / \mathrm{L}$, micrograms per liter; <, less than; WTP, water-treatment plant; F, finished water; I, intake; CW, collector well; DS, downstream; bold, value exceeded detection or reporting level]

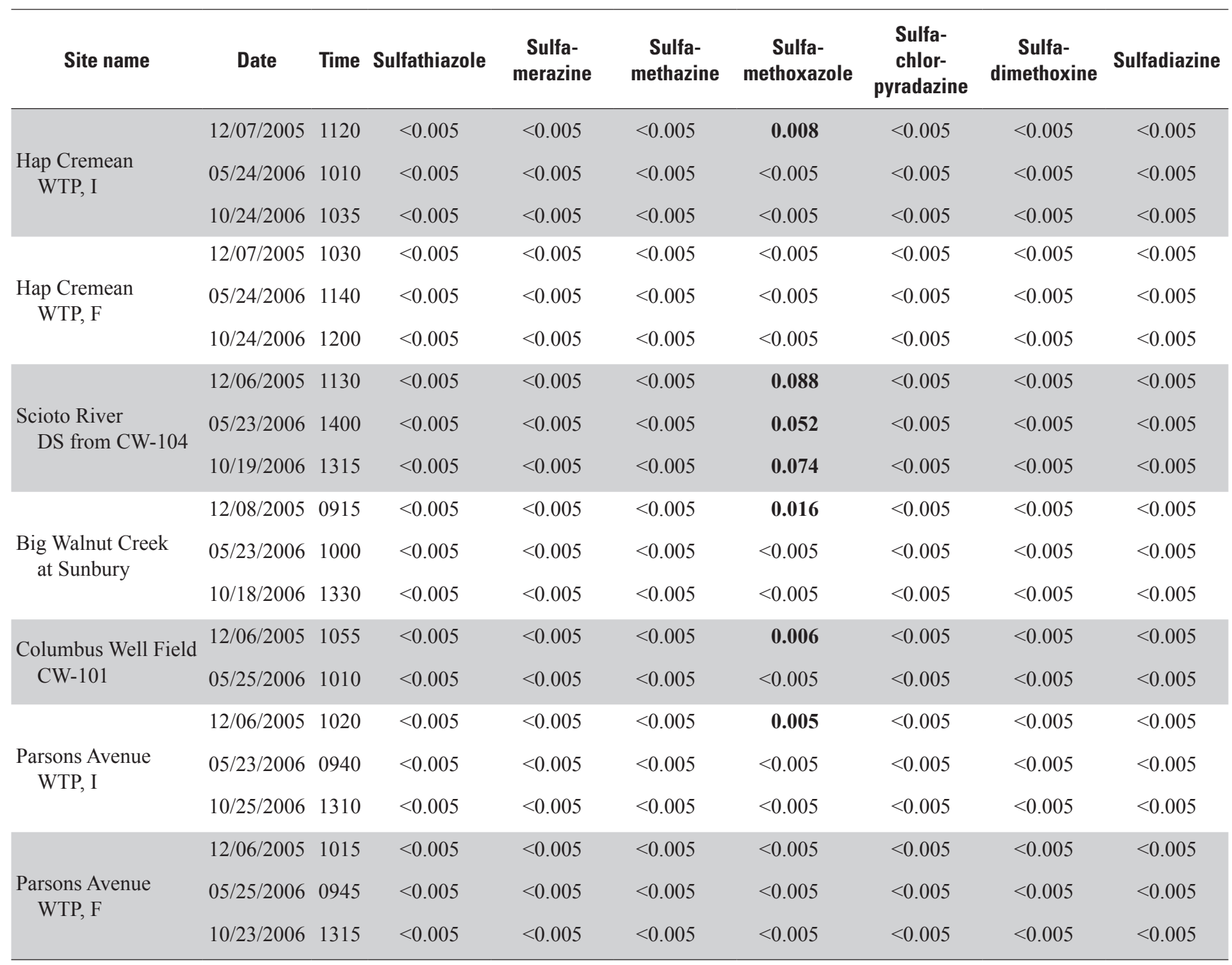




\section{Antibiotic Compounds in Source Water and Finished Drinking Water, Upper Scioto River Basin, Ohio, 2005-6}

Table 1-2. Water-quality analyses from sampling locations in the upper Scioto River Basin, Ohio, 2005-6.-Continued

$[\mu \mathrm{g} / \mathrm{L}$, micrograms per liter; <, less than; WTP, water-treatment plant; F, finished water; I, intake; CW, collector well; DS, downstream; bold, value exceeded detection or reporting level]

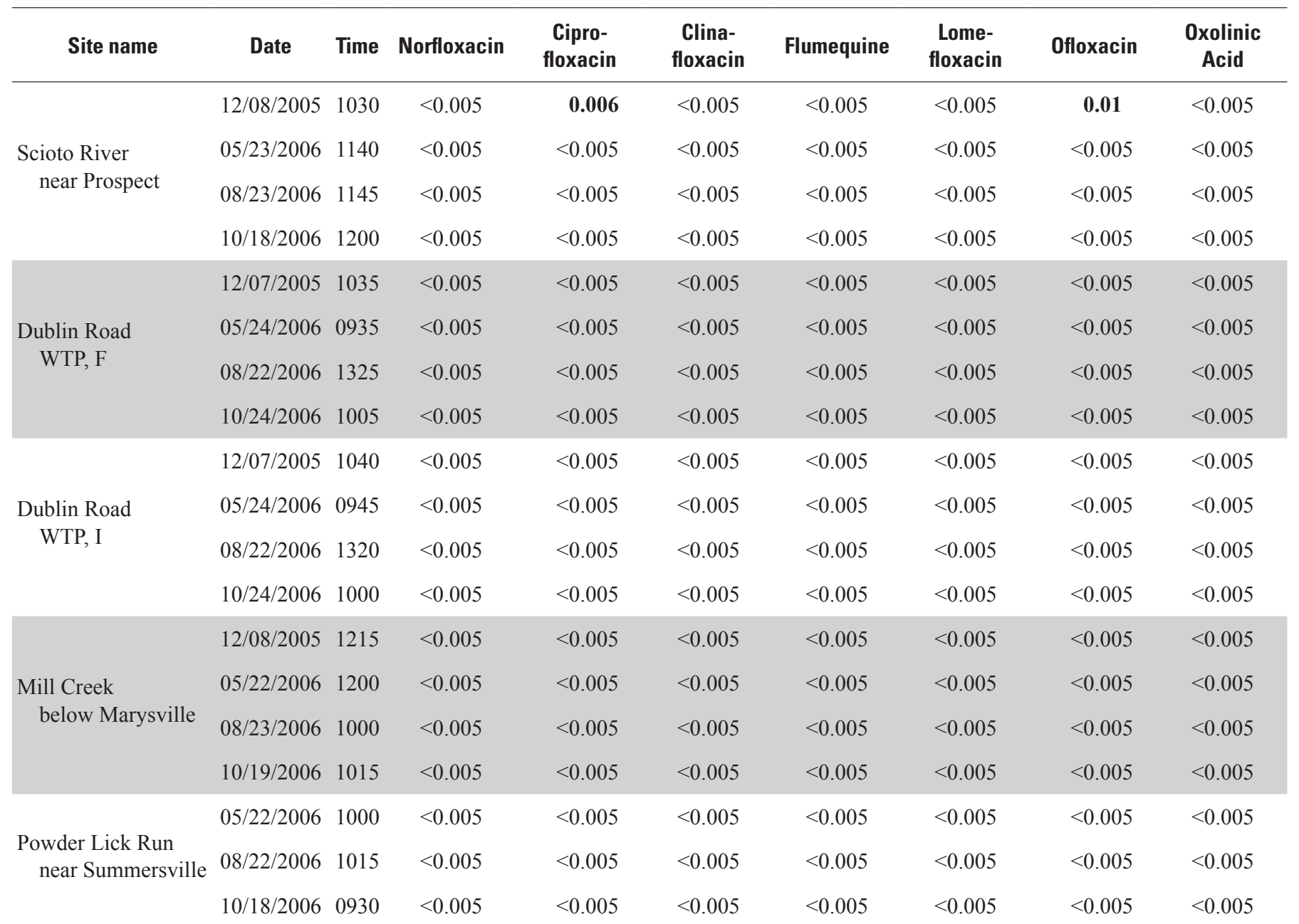


Table 1-2. Water-quality analyses from sampling locations in the upper Scioto River Basin, Ohio, 2005-6.-Continued

$[\mu \mathrm{g} / \mathrm{L}$, micrograms per liter; <, less than; WTP, water-treatment plant; F, finished water; I, intake; CW, collector well; DS, downstream; bold, value exceeded detection or reporting level]

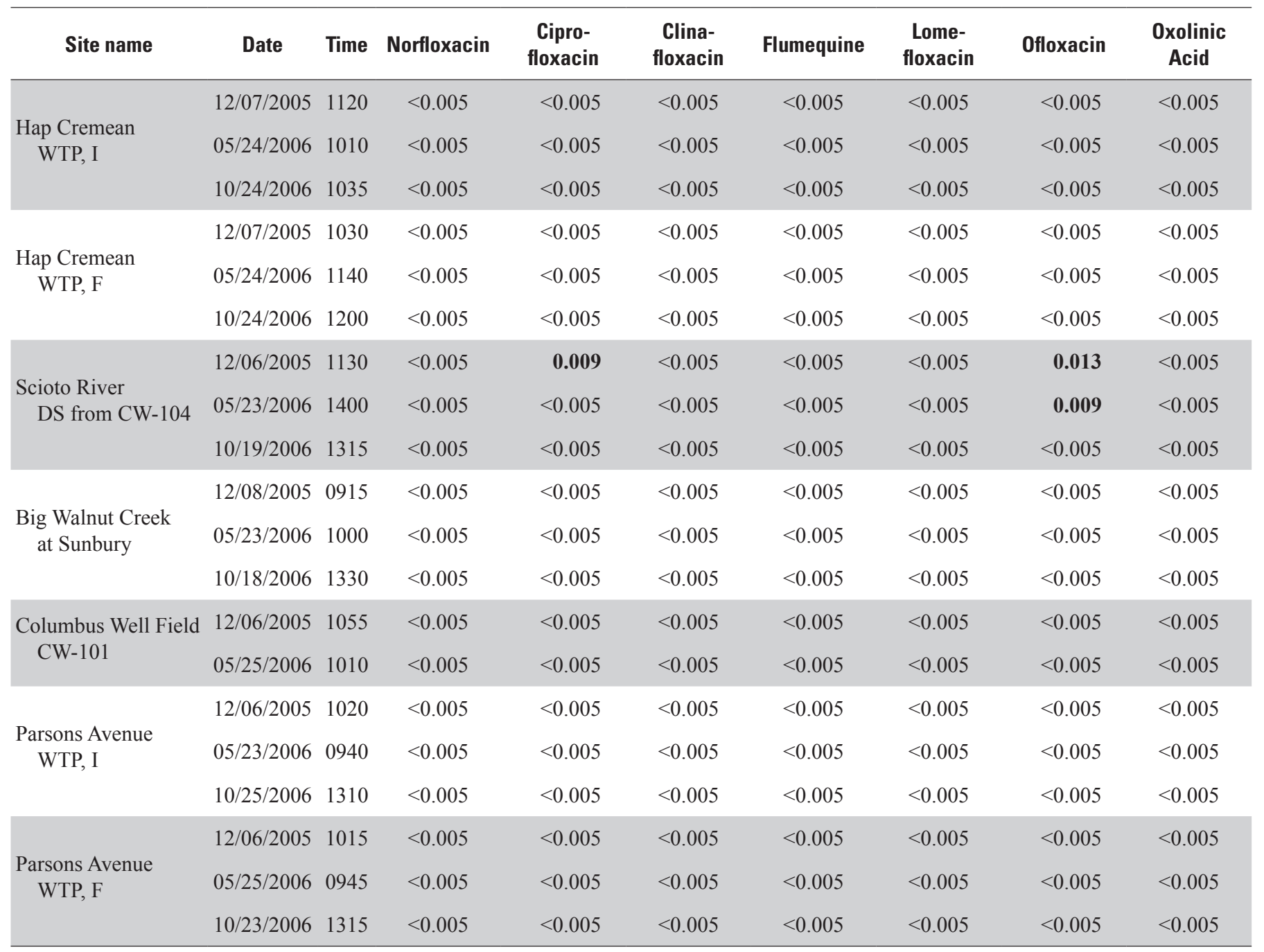




\section{Antibiotic Compounds in Source Water and Finished Drinking Water, Upper Scioto River Basin, Ohio, 2005-6}

Table 1-2. Water-quality analyses from sampling locations in the upper Scioto River Basin, 0hio, 2005-6.-Continued

$[\mu \mathrm{g} / \mathrm{L}$, micrograms per liter; <, less than; WTP, water-treatment plant; F, finished water; I, intake; CW, collector well; DS, downstream; bold, value exceeded detection or reporting level]

\begin{tabular}{|c|c|c|c|c|c|c|c|c|c|}
\hline Site name & Date & Time & Sarafloxacin & Azithromycin & Tylosin & $\begin{array}{l}\text { Virginia- } \\
\text { mycin }\end{array}$ & $\begin{array}{c}\text { Erythromycin- } \\
\qquad \mathrm{H}_{2} \mathrm{O}\end{array}$ & Erythromycin & $\begin{array}{l}\text { Roxithro- } \\
\text { mycin }\end{array}$ \\
\hline \multirow{3}{*}{$\begin{array}{l}\text { Scioto River near } \\
\text { Prospect }\end{array}$} & $12 / 08 / 2005$ & 1030 & $<0.005$ & 0.011 & $<0.005$ & $<0.005$ & 0.014 & 0.015 & $<0.005$ \\
\hline & $05 / 23 / 2006$ & 1140 & $<0.005$ & $<0.005$ & $<0.005$ & $<0.005$ & $<0.005$ & 0.007 & $<0.005$ \\
\hline & $08 / 23 / 2006$ & 1145 & $<0.005$ & $<0.005$ & $<0.005$ & $<0.005$ & 0.013 & 0.022 & $<0.005$ \\
\hline \multirow{4}{*}{$\begin{array}{l}\text { Dublin Road } \\
\text { WTP, F }\end{array}$} & $12 / 07 / 2005$ & 1035 & $<0.005$ & 0.025 & $<0.005$ & $<0.005$ & $<0.005$ & $<0.005$ & $<0.005$ \\
\hline & $05 / 24 / 2006$ & 0935 & $<0.005$ & $<0.005$ & $<0.005$ & $<0.005$ & $<0.005$ & $<0.005$ & $<0.005$ \\
\hline & $08 / 22 / 2006$ & 1325 & $<0.005$ & $<0.005$ & $<0.005$ & $<0.005$ & $<0.005$ & $<0.005$ & $<0.005$ \\
\hline & $10 / 24 / 2006$ & 1005 & $<0.005$ & $<0.005$ & $<0.005$ & $<0.005$ & $<0.005$ & $<0.005$ & $<0.005$ \\
\hline \multirow{2}{*}{$\begin{array}{l}\text { Dublin Road } \\
\text { WTP, I }\end{array}$} & $08 / 22 / 2006$ & 1320 & $<0.005$ & $<0.005$ & $<0.005$ & $<0.005$ & $<0.005$ & $<0.005$ & $<0.005$ \\
\hline & $10 / 24 / 2006$ & 1000 & $<0.005$ & $<0.005$ & $<0.005$ & $<0.005$ & $<0.005$ & $<0.005$ & $<0.005$ \\
\hline \multirow{4}{*}{$\begin{array}{l}\text { Mill Creek below } \\
\text { Marysville }\end{array}$} & $12 / 08 / 2005$ & 1215 & $<0.005$ & $<0.005$ & $<0.005$ & $<0.005$ & $<0.005$ & $<0.005$ & $<0.005$ \\
\hline & $05 / 22 / 2006$ & 1200 & $<0.005$ & $<0.005$ & $<0.005$ & $<0.005$ & $<0.005$ & $<0.005$ & $<0.005$ \\
\hline & $08 / 23 / 2006$ & 1000 & $<0.005$ & $<0.005$ & $<0.005$ & $<0.005$ & $<0.005$ & $<0.005$ & $<0.005$ \\
\hline & $10 / 19 / 2006$ & 1015 & $<0.005$ & $<0.005$ & $<0.005$ & $<0.005$ & $<0.005$ & $<0.005$ & $<0.005$ \\
\hline $\begin{array}{l}\text { Powder Lick Run } \\
\text { near Summersville }\end{array}$ & $05 / 22 / 2006$ & 1000 & $<0.005$ & $<0.005$ & $<0.005$ & $<0.005$ & $<0.005$ & $<0.005$ & $<0.005$ \\
\hline
\end{tabular}


Table 1-2. Water-quality analyses from sampling locations in the upper Scioto River Basin, Ohio, 2005-6.-Continued

$[\mu \mathrm{g} / \mathrm{L}$, micrograms per liter; <, less than; WTP, water-treatment plant; F, finished water; I, intake; CW, collector well; DS, downstream; bold, value exceeded detection or reporting level]

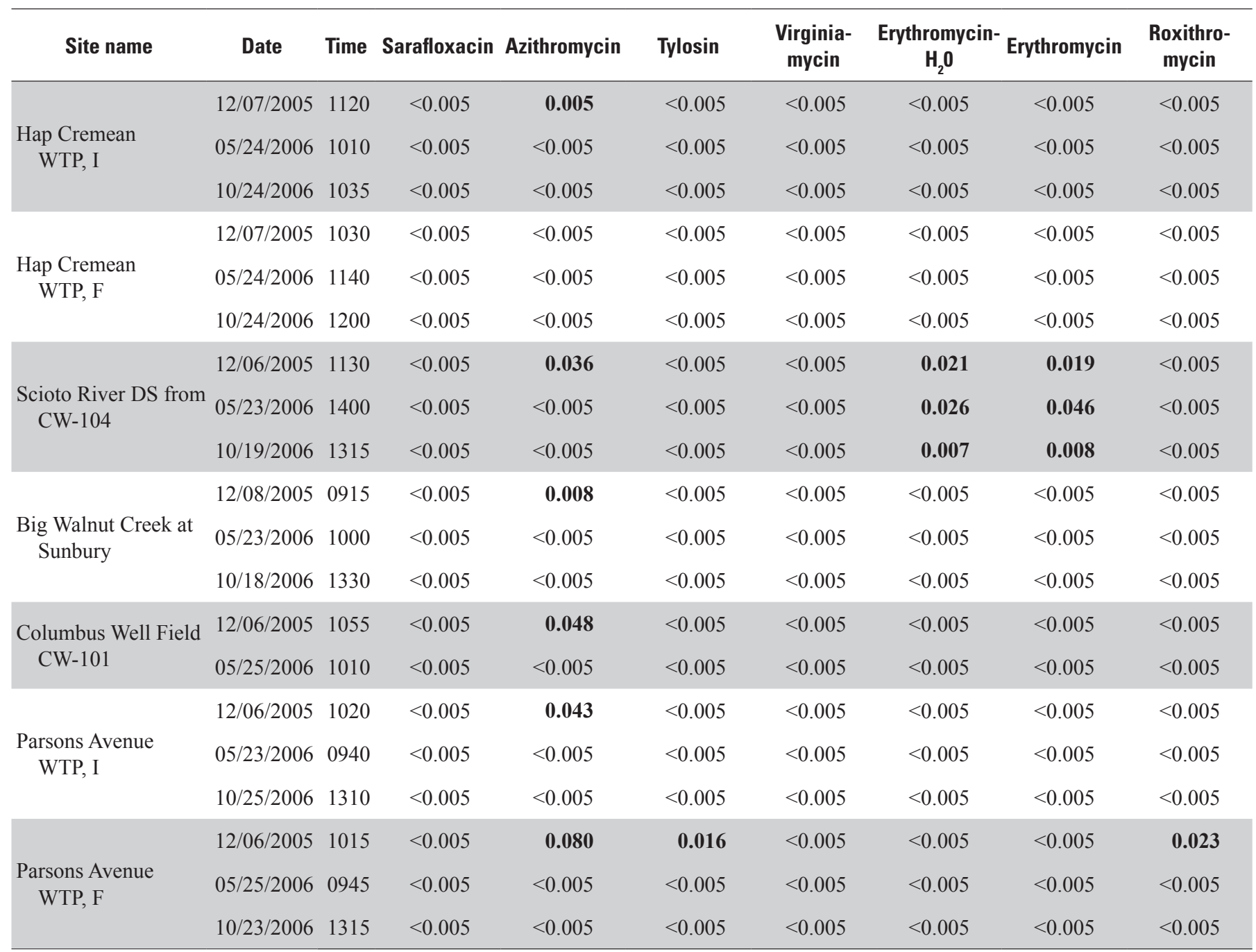




\section{Antibiotic Compounds in Source Water and Finished Drinking Water, Upper Scioto River Basin, 0hio, 2005-6}

Table 1-2. Water-quality analyses from sampling locations in the upper Scioto River Basin, Ohio, 2005-6.-Continued

$[\mu \mathrm{g} / \mathrm{L}$, micrograms per liter; <, less than; WTP, water-treatment plant; F, finished water; I, intake; CW, collector well; DS, downstream; bold, value exceeded detection or reporting level]

\begin{tabular}{|c|c|c|c|c|c|c|c|c|c|}
\hline Site name & Date & Time & Amoxicillin & Ampicillin & Cefotaxime & Cloxacillin & Oxacillin & Penicillin G & Penicillin V \\
\hline \multirow{3}{*}{$\begin{array}{l}\text { Scioto River } \\
\text { near Prospect }\end{array}$} & $05 / 23 / 2006$ & 1140 & $<0.010$ & $<0.010$ & $<0.010$ & $<0.010$ & $<0.010$ & $<0.010$ & $<0.010$ \\
\hline & 08/23/2006 & 1145 & $<0.010$ & $<0.010$ & $<0.010$ & $<0.010$ & $<0.010$ & $<0.010$ & $<0.010$ \\
\hline & $10 / 18 / 2006$ & 1200 & $<0.010$ & $<0.010$ & $<0.010$ & $<0.010$ & $<0.010$ & $<0.010$ & $<0.010$ \\
\hline \multirow{3}{*}{$\begin{array}{l}\text { Dublin Road } \\
\text { WTP, F }\end{array}$} & $05 / 24 / 2006$ & 0935 & $<0.010$ & $<0.010$ & $<0.010$ & $<0.010$ & $<0.010$ & $<0.010$ & $<0.010$ \\
\hline & $08 / 22 / 2006$ & 1325 & $<0.010$ & $<0.010$ & $<0.010$ & $<0.010$ & $<0.010$ & $<0.010$ & $<0.010$ \\
\hline & $10 / 24 / 2006$ & 1005 & $<0.010$ & $<0.010$ & $<0.010$ & $<0.010$ & $<0.010$ & $<0.010$ & $<0.010$ \\
\hline $\begin{array}{l}\text { Dublin Road } \\
\text { WTP, I }\end{array}$ & $10 / 24 / 2006$ & 1000 & $<0.010$ & $<0.010$ & $<0.010$ & $<0.010$ & $<0.010$ & $<0.010$ & $<0.010$ \\
\hline \multirow{4}{*}{$\begin{array}{l}\text { Mill Creek } \\
\text { below Marysville }\end{array}$} & $12 / 08 / 2005$ & 1215 & $<0.010$ & $<0.010$ & $<0.010$ & $<0.010$ & $<0.010$ & $<0.010$ & $<0.010$ \\
\hline & $05 / 22 / 2006$ & 1200 & $<0.010$ & $<0.010$ & $<0.010$ & $<0.010$ & $<0.010$ & $<0.010$ & $<0.010$ \\
\hline & $08 / 23 / 2006$ & 1000 & $<0.010$ & $<0.010$ & $<0.010$ & $<0.010$ & $<0.010$ & $<0.010$ & $<0.010$ \\
\hline & 10/19/2006 & 1015 & $<0.010$ & $<0.010$ & $<0.010$ & $<0.010$ & $<0.010$ & $<0.010$ & $<0.010$ \\
\hline \multirow[b]{2}{*}{$\begin{array}{l}\text { Powder Lick Run } \\
\text { near Summersville }\end{array}$} & $05 / 22 / 2006$ & 1000 & $<0.010$ & $<0.010$ & $<0.010$ & $<0.010$ & $<0.010$ & $<0.010$ & $<0.010$ \\
\hline & 08/22/2006 & 1015 & $<0.010$ & $<0.010$ & $<0.010$ & $<0.010$ & $<0.010$ & $<0.010$ & $<0.010$ \\
\hline
\end{tabular}


Table 1-2. Water-quality analyses from sampling locations in the upper Scioto River Basin, Ohio, 2005-6.-Continued

$[\mu \mathrm{g} / \mathrm{L}$, micrograms per liter; <, less than; WTP, water-treatment plant; F, finished water; I, intake; CW, collector well; DS, downstream; bold, value exceeded detection or reporting level]

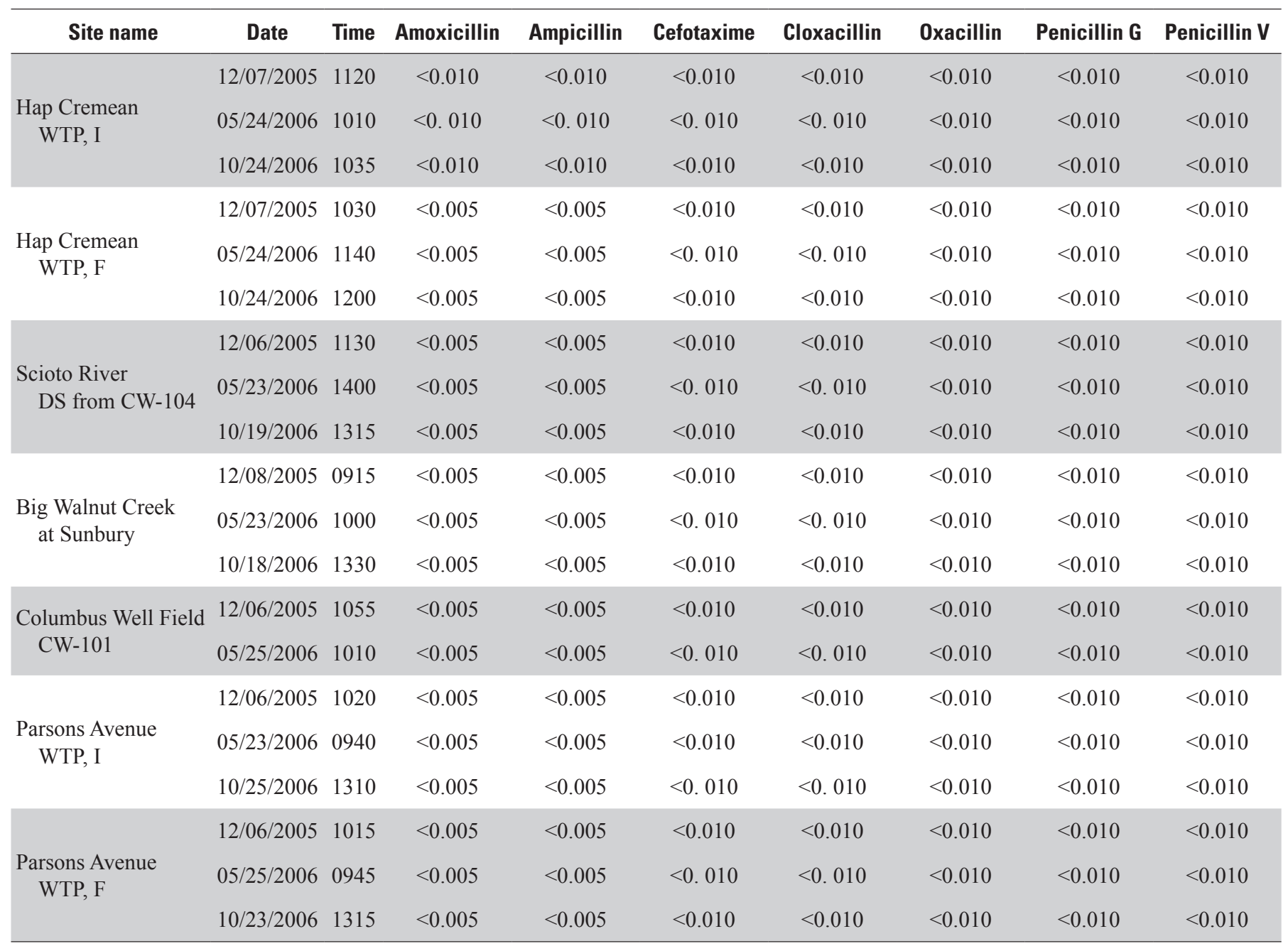


Table 1-3. Quality-control analyses from sampling locations in the upper Scioto River Basin, Ohio, 2005-6.

[All constituent concentrations in micrograms per liter; —, not measured; <, less than; WTP, water-treatment plant; DS, downstream; CW, collector well; F, finished water; I, intake; bold, value exceeded detection or reporting level]

\begin{tabular}{|c|c|c|c|c|c|c|c|c|c|}
\hline Site name & Date & Time & Lincomycin & Carbadox & $\begin{array}{c}\text { Tri- } \\
\text { methoprim }\end{array}$ & Ormetoprim & Tetracycline & $\begin{array}{c}\text { Anhydro- } \\
\text { tetracycline }\end{array}$ & $\begin{array}{c}\text { Epi- } \\
\text { anhydro- } \\
\text { tetracycline }\end{array}$ \\
\hline $\begin{array}{l}\text { Dublin Road } \\
\text { WTP, I }\end{array}$ & $12 / 07 / 2005$ & 1041 & $<0.005$ & $<0.005$ & $<0.005$ & $<0.005$ & $<0.010$ & $<0.010$ & $<0.010$ \\
\hline $\begin{array}{l}\text { Hap Cremean } \\
\text { WTP, F }\end{array}$ & $10 / 24 / 2006$ & 1039 & $<0.005$ & $<0.005$ & $<0.005$ & $<0.005$ & $<0.010$ & $<0.010$ & $<0.010$ \\
\hline $\begin{array}{l}\text { Big Walnut Creek } \\
\text { at Sunbury }\end{array}$ & $05 / 23 / 2006$ & 0959 & $<0.005$ & $<0.005$ & $<0.005$ & $<0.005$ & $<0.010$ & $<0.010$ & $<0.010$ \\
\hline \multicolumn{10}{|c|}{ Replicates } \\
\hline $\begin{array}{l}\text { Powder Lick Run } \\
\text { near Summersville }\end{array}$ & $05 / 22 / 2006$ & 1001 & 0.005 & $<0.005$ & $<0.005$ & $<0.005$ & $<0.010$ & $<0.010$ & $<0.010$ \\
\hline $\begin{array}{l}\text { Columbus Well Field } \\
\text { CW-101 }\end{array}$ & $05 / 25 / 2006$ & 1011 & $<0.005$ & $<0.005$ & $<0.005$ & $<0.005$ & $<0.010$ & $<0.010$ & $<0.010$ \\
\hline
\end{tabular}

Table 1-3. Quality-control analyses from sampling locations in the upper Scioto River Basin, Ohio, 2005-6.-Continued

[All constituent concentrations in micrograms per liter; —, not measured; <, less than; WTP, water-treatment plant; DS, downstream; CW, collector well; F, finished water; I, intake; bold, value exceeded detection or reporting level]

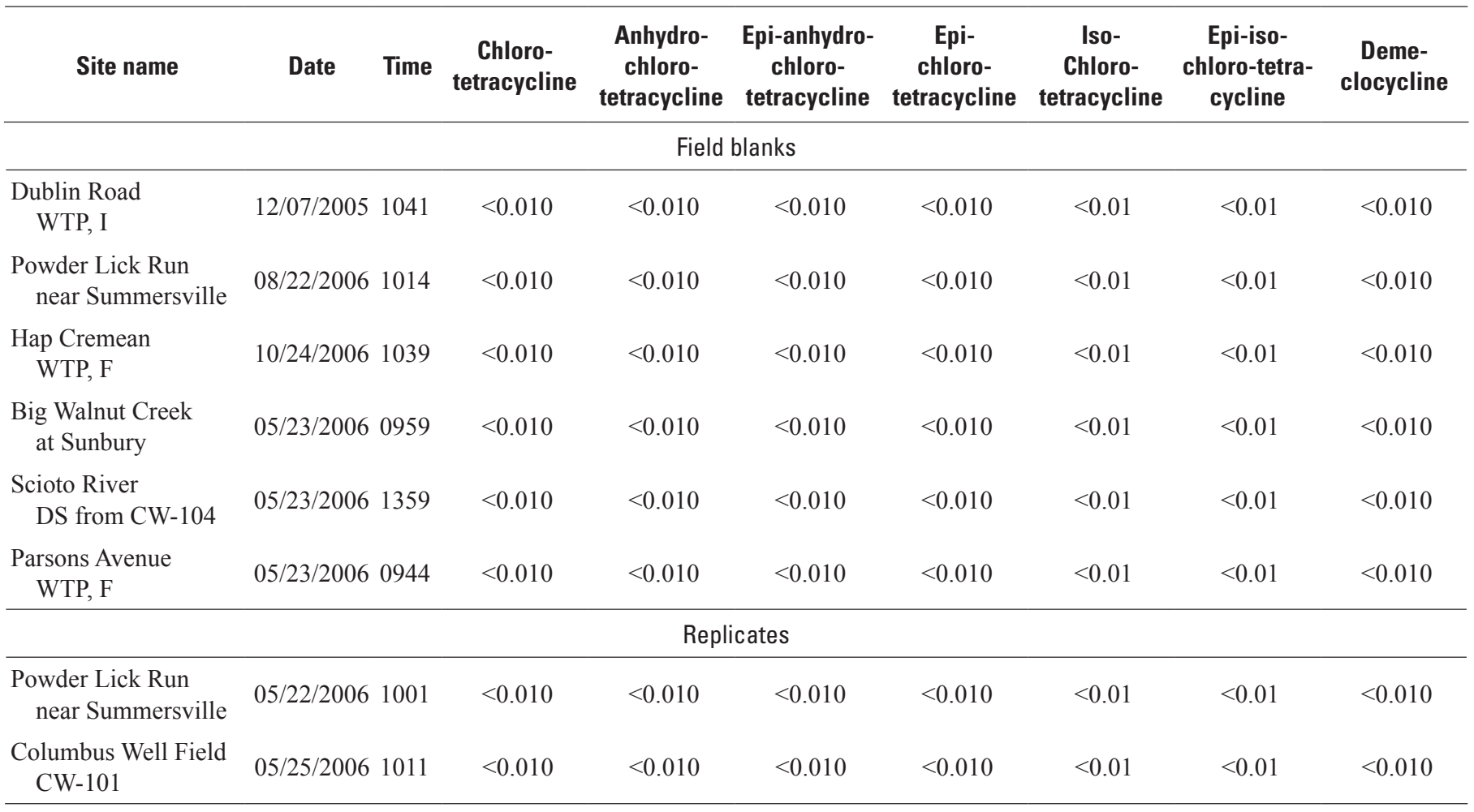


Table 1-3. Quality-control analyses from sampling locations in the upper Scioto River Basin, 0hio, 2005-6.-Continued

[All constituent concentrations in micrograms per liter; —, not measured; <, less than; WTP, water-treatment plant; DS, downstream; CW, collector well; F, finished water; I, intake; bold, value exceeded detection or reporting level]

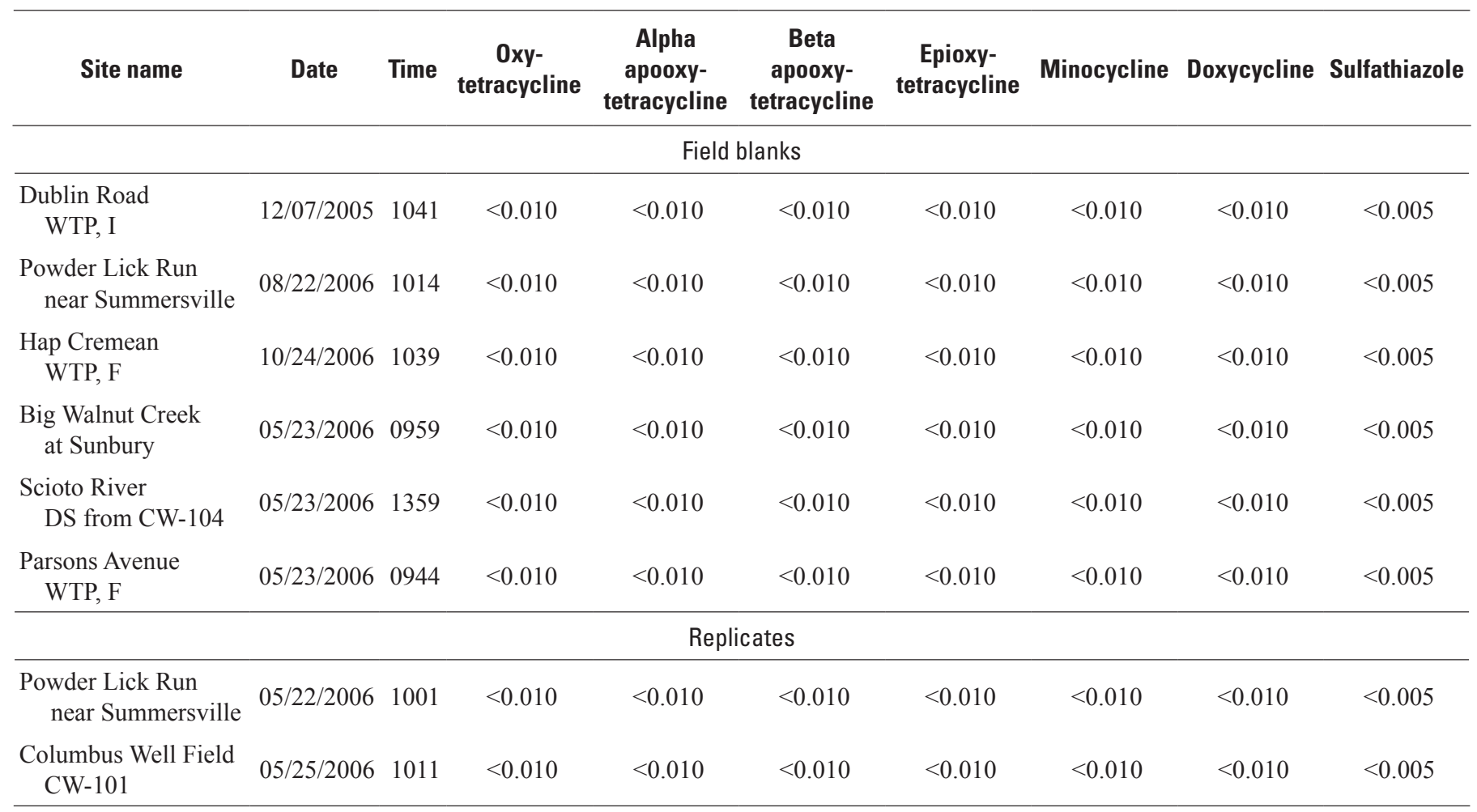

Table 1-3. Quality-control analyses from sampling locations in the upper Scioto River Basin, Ohio, 2005-6.-Continued

[All constituent concentrations in micrograms per liter; — not measured; <, less than; WTP, water-treatment plant; DS, downstream; CW, collector well; F, finished water; I, intake; bold, value exceeded detection or reporting level]

\begin{tabular}{|c|c|c|c|c|c|c|c|c|c|}
\hline Site name & Date & Time & $\begin{array}{l}\text { Sulfa- } \\
\text { merazine }\end{array}$ & $\begin{array}{c}\text { Sulfa- } \\
\text { methazine }\end{array}$ & $\begin{array}{c}\text { Sulfa- } \\
\text { methoxazole }\end{array}$ & $\begin{array}{c}\text { Sulfa- } \\
\text { chlor- } \\
\text { pyradazine }\end{array}$ & $\begin{array}{l}\text { Sulfa- } \\
\text { dimethoxine }\end{array}$ & Sulfadiazine & Norfloxacin \\
\hline \multicolumn{10}{|c|}{ Field blanks } \\
\hline $\begin{array}{l}\text { Dublin Road } \\
\text { WTP, I }\end{array}$ & $12 / 07 / 2005$ & 1041 & $<0.005$ & $<0.005$ & $<0.005$ & $<0.005$ & $<0.005$ & $<0.005$ & $<0.005$ \\
\hline $\begin{array}{l}\text { Powder Lick Run } \\
\text { near Summersville }\end{array}$ & $08 / 22 / 2006$ & 1014 & $<0.005$ & $<0.005$ & $<0.005$ & $<0.005$ & $<0.005$ & $<0.005$ & $<0.005$ \\
\hline $\begin{array}{l}\text { Hap Cremean } \\
\text { WTP, F }\end{array}$ & $10 / 24 / 2006$ & 1039 & $<0.005$ & $<0.005$ & $<0.005$ & $<0.005$ & $<0.005$ & $<0.005$ & $<0.005$ \\
\hline $\begin{array}{l}\text { Big Walnut Creek } \\
\text { at Sunbury }\end{array}$ & $05 / 23 / 2006$ & 0959 & $<0.005$ & $<0.005$ & $<0.005$ & $<0.005$ & $<0.005$ & $<0.005$ & $<0.005$ \\
\hline $\begin{array}{l}\text { Scioto River } \\
\text { DS from CW-104 }\end{array}$ & $05 / 23 / 2006$ & 1359 & $<0.005$ & $<0.005$ & $<0.005$ & $<0.005$ & $<0.005$ & $<0.005$ & $<0.005$ \\
\hline $\begin{array}{l}\text { Parsons Avenue } \\
\text { WTP, F }\end{array}$ & $05 / 23 / 2006$ & 0944 & $<0.005$ & $<0.005$ & $<0.005$ & $<0.005$ & $<0.005$ & $<0.005$ & $<0.005$ \\
\hline \multicolumn{10}{|c|}{ Replicates } \\
\hline $\begin{array}{l}\text { Powder Lick Run } \\
\text { near Summersville }\end{array}$ & $05 / 22 / 2006$ & 1001 & $<0.005$ & $<0.005$ & $<0.005$ & $<0.005$ & $<0.005$ & $<0.005$ & $<0.005$ \\
\hline $\begin{array}{l}\text { Columbus Well Field } \\
\text { CW-101 }\end{array}$ & $05 / 25 / 2006$ & 1011 & $<0.005$ & $<0.005$ & $<0.005$ & $<0.005$ & $<0.005$ & $<0.005$ & $<0.005$ \\
\hline
\end{tabular}


Table 1-3. Quality-control analyses from sampling locations in the upper Scioto River Basin, Ohio, 2005-6.-Continued

[All constituent concentrations in micrograms per liter; — not measured; <, less than; WTP, water-treatment plant; DS, downstream; CW, collector well; F, finished water; I, intake; bold, value exceeded detection or reporting level]

\begin{tabular}{|c|c|c|c|c|c|c|c|c|c|c|}
\hline Site name & Date & Time & $\begin{array}{l}\text { Cipro- } \\
\text { floxacin }\end{array}$ & $\begin{array}{l}\text { Clina- } \\
\text { floxacin }\end{array}$ & Flumequine & $\begin{array}{l}\text { Lome- } \\
\text { floxacin }\end{array}$ & Ofloxacin & $\begin{array}{l}\text { Oxolinic } \\
\text { Acid }\end{array}$ & $\begin{array}{l}\text { Sara- } \\
\text { floxacin }\end{array}$ & $\begin{array}{l}\text { Azithro- } \\
\text { mycin }\end{array}$ \\
\hline \multicolumn{11}{|c|}{ Field blanks } \\
\hline $\begin{array}{l}\text { Dublin Road } \\
\text { WTP, I }\end{array}$ & $12 / 07 / 2005$ & 1041 & $<0.005$ & $<0.005$ & $<0.005$ & $<0.005$ & $<0.005$ & $<0.005$ & $<0.005$ & $<0.005$ \\
\hline $\begin{array}{l}\text { Powder Lick Run } \\
\text { near Summersville }\end{array}$ & 08/22/2006 & 1014 & $<0.005$ & $<0.005$ & $<0.005$ & $<0.005$ & $<0.005$ & $<0.005$ & $<0.005$ & $<0.005$ \\
\hline $\begin{array}{l}\text { Hap Cremean } \\
\text { WTP, F }\end{array}$ & $10 / 24 / 2006$ & 1039 & $<0.005$ & $<0.005$ & $<0.005$ & $<0.005$ & $<0.005$ & $<0.005$ & $<0.005$ & $<0.005$ \\
\hline $\begin{array}{l}\text { Big Walnut Creek } \\
\text { at Sunbury }\end{array}$ & $05 / 23 / 2006$ & 0959 & $<0.005$ & $<0.005$ & $<0.005$ & $<0.005$ & $<0.005$ & $<0.005$ & $<0.005$ & $<0.005$ \\
\hline $\begin{array}{l}\text { Scioto River } \\
\text { DS from CW-104 }\end{array}$ & $05 / 23 / 2006$ & 1359 & $<0.005$ & $<0.005$ & $<0.005$ & $<0.005$ & $<0.005$ & $<0.005$ & $<0.005$ & $<0.005$ \\
\hline \multicolumn{11}{|c|}{ Replicates } \\
\hline $\begin{array}{l}\text { Powder Lick Run } \\
\text { near Summersville }\end{array}$ & $05 / 22 / 2006$ & 1001 & $<0.005$ & $<0.005$ & $<0.005$ & $<0.005$ & $<0.005$ & $<0.005$ & $<0.005$ & $<0.005$ \\
\hline $\begin{array}{l}\text { Columbus Well Field } \\
\text { CW-101 }\end{array}$ & $05 / 25 / 2006$ & 1011 & $<0.005$ & $<0.005$ & $<0.005$ & $<0.005$ & $<0.005$ & $<0.005$ & $<0.005$ & $<0.005$ \\
\hline
\end{tabular}

Table 1-3. Quality-control analyses from sampling locations in the upper Scioto River Basin, Ohio, 2005-6.-Continued

[All constituent concentrations in micrograms per liter; — not measured; <, less than; WTP, water-treatment plant; DS, downstream; CW, collector well; F, finished water; I, intake; bold, value exceeded detection or reporting level]

\begin{tabular}{|c|c|c|c|c|c|c|c|c|c|}
\hline Site name & Date & Time & Tylosin & Virginiamycin & $\begin{array}{l}\text { Erythro- } \\
\text { mycin- } \mathrm{H}_{2} \mathrm{O}\end{array}$ & Erythromycin & $\begin{array}{l}\text { Roxithro- } \\
\text { mycin }\end{array}$ & Amoxocillin & Ampicillin \\
\hline \multicolumn{10}{|c|}{ Field blanks } \\
\hline $\begin{array}{l}\text { Dublin Road } \\
\text { WTP, I }\end{array}$ & $12 / 07 / 2005$ & 1041 & $<0.005$ & $<0.005$ & $<0.005$ & $<0.005$ & $<0.005$ & $<0.010$ & $<0.010$ \\
\hline $\begin{array}{l}\text { Powder Lick } \\
\text { near Summersville }\end{array}$ & $08 / 22 / 2006$ & 1014 & $<0.005$ & $<0.005$ & $<0.005$ & $<0.005$ & $<0.005$ & $<0.010$ & $<0.010$ \\
\hline $\begin{array}{l}\text { Hap Cremean } \\
\text { WTP, F }\end{array}$ & $10 / 24 / 2006$ & 1039 & $<0.005$ & $<0.005$ & $<0.005$ & $<0.005$ & $<0.005$ & $<0.010$ & $<0.010$ \\
\hline $\begin{array}{l}\text { Big Walnut Creek } \\
\text { at Sunbury }\end{array}$ & $05 / 23 / 2006$ & 0959 & $<0.005$ & $<0.005$ & $<0.005$ & $<0.005$ & $<0.005$ & $<0.010$ & $<0.010$ \\
\hline $\begin{array}{l}\text { Scioto River } \\
\text { DS from CW-104 }\end{array}$ & $05 / 23 / 2006$ & 1359 & $<0.005$ & $<0.005$ & $<0.005$ & $<0.005$ & $<0.005$ & $<0.010$ & $<0.010$ \\
\hline \multicolumn{10}{|c|}{ Replicates } \\
\hline $\begin{array}{l}\text { Powder Lick Run } \\
\text { near Summersville }\end{array}$ & $05 / 22 / 2006$ & 1001 & $<0.005$ & $<0.005$ & $<0.005$ & $<0.005$ & $<0.005$ & $<0.010$ & $<0.010$ \\
\hline $\begin{array}{l}\text { Columbus Well Field } \\
\text { CW-101 }\end{array}$ & $05 / 25 / 2006$ & 1011 & $<0.005$ & $<0.005$ & $<0.005$ & $<0.005$ & $<0.005$ & $<0.010$ & $<0.010$ \\
\hline
\end{tabular}


Table 1-3. Quality-control analyses from sampling locations in the upper Scioto River Basin, Ohio, 2005-6.-Continued

[All constituent concentrations in micrograms per liter; — not measured; <, less than; WTP, water-treatment plant; DS, downstream; $\mathrm{CW}$, collector well; F, finished water; I, intake; bold, value exceeded detection or reporting level]

\begin{tabular}{|c|c|c|c|c|c|c|c|}
\hline Site name & Date & Time & Cefotaxime & Cloxacillin & Oxacillin & Penicilln G & Penicillin V \\
\hline \multicolumn{8}{|c|}{ Field blanks } \\
\hline $\begin{array}{l}\text { Dublin Road } \\
\text { WTP, I }\end{array}$ & $12 / 07 / 2005$ & 1041 & $<0.010$ & $<0.010$ & $<0.010$ & $<0.010$ & $<0.010$ \\
\hline $\begin{array}{l}\text { Powder Lick Run } \\
\text { near Summersville }\end{array}$ & $08 / 22 / 2006$ & 1014 & $<0.010$ & $<0.010$ & $<0.010$ & $<0.010$ & $<0.010$ \\
\hline $\begin{array}{l}\text { Hap Cremean } \\
\text { WTP, F }\end{array}$ & $10 / 24 / 2006$ & 1039 & $<0.010$ & $<0.010$ & $<0.010$ & $<0.010$ & $<0.010$ \\
\hline $\begin{array}{l}\text { Big Walnut Creek } \\
\text { at Sunbury }\end{array}$ & $05 / 23 / 2006$ & 0959 & $<0.010$ & $<0.010$ & $<0.010$ & $<0.010$ & $<0.010$ \\
\hline $\begin{array}{l}\text { Scioto River } \\
\text { DS from CWl-104 }\end{array}$ & $05 / 23 / 2006$ & 1359 & $<0.010$ & $<0.010$ & $<0.010$ & $<0.010$ & $<0.010$ \\
\hline $\begin{array}{l}\text { Parsons Avenue } \\
\text { WTP, F }\end{array}$ & $05 / 23 / 2006$ & 0944 & $<0.010$ & $<0.010$ & $<0.010$ & $<0.010$ & $<0.010$ \\
\hline \multicolumn{8}{|c|}{ Replicates } \\
\hline $\begin{array}{l}\text { Powder Lick Run } \\
\text { near Summersville }\end{array}$ & $05 / 22 / 2006$ & 1001 & $<0.010$ & $<0.010$ & $<0.010$ & $<0.010$ & $<0.010$ \\
\hline $\begin{array}{l}\text { Columbus Well Field } \\
\text { CW-101 }\end{array}$ & $05 / 25 / 2006$ & 1011 & $<0.010$ & $<0.010$ & $<0.010$ & $<0.010$ & $<0.010$ \\
\hline
\end{tabular}




\section{Appendix 2. Sample Analysis}

Samples were extracted for the beta lactam and macrolides (BLM) and sulfonamides and quinolines (SQ) methods using HLB Prospekt cartridges (Waters Corp., Milford, Mass.) and for the tetracyclines (TET) method using a proprietary Glyphosate Prospekt cartridge (Spark Holland, Emmen, The Netherlands). Simatone was used as an internal standard for all three methods; the surrogate standards were oleandomycin for the BLM method, nalidixic acid and ${ }^{13} \mathrm{C}_{6}$ sulfamethazine for the SQ method, and meclocycline for the TET method. A $1.23 \mathrm{ng} / \mu \mathrm{L}$ solution of the internal standard, simatone, was diluted 1:20 for the BLM and SQ methods and 1:40 for the TET method. The diluted standard was added to an amber 2-mL chromatography vial and placed on the LC autosampler tray.

Samples were prepared for analysis by pipetting a 10-mL aliquot of each sample into 11-mL glass crimp-top vials. For the BLM and SQ methods, $75 \mathrm{~mL}$ of $6.67 \mathrm{ng} / \mathrm{ml}$ surrogate solutions were made up in distilled water, and for the TET method, in a 5\% diNa-EDTA solution; $750 \mu \mathrm{L}$ of the respective surrogate was added to each sample, standard, and blank. Standard curves were prepared for each method by diluting the respective $1-\mathrm{ng} / \mu \mathrm{L}$ standard mix to $1 \mathrm{ng} / \mathrm{mL}$ with distilled water. Standard solutions, $10 \mathrm{~mL}$ in volume, were then made at concentrations of $0.01,0.02,0.05,0.1,0.2,0.5$ and $1.0 \mu \mathrm{g} / \mathrm{L}$.

A duplicate sample, a 0.5 - or $1.0-\mu \mathrm{g} / \mathrm{L}$ matrix-spiked sample, and a blank were analyzed after every 10 samples and a $1.0 \mu \mathrm{g} / \mathrm{L}$ standard solution after every 20 . All standard solutions, blanks, and matrix spikes were treated the same as the water samples. Sample modifier solutions were added to each sample by the online SPE autosampler just prior to extraction and were prepared for the SQ and TET method by adding $250 \mu \mathrm{L}$ of formic acid to $9.75 \mathrm{~mL}$ of deionized water, and for the BLM method by adding $10 \mathrm{ml}$ of a 10 percent $\mathrm{NaCl}$ solution with 0.5 percent diNa-EDTA to an $11-\mathrm{mL}$ crimp top vial.

All of the prepared samples were loaded on the online solid phase extraction (SPE) Triathalon autosampler. During analysis, the online SPE lines were rinsed with solvents and solutions configured with the Triathalon autosampler and the high-pressure dispenser. The cartridges were rinsed immediately prior to extraction. A volume of $10 \mathrm{ml}$ of sample was drawn into a Teflon sample loop and dispensed through the Prospekt SPE cartridge.

The antibiotics for each method were eluted with $750 \mu \mathrm{L}$ of ACN and separated using a liquid chromatography (LC) gradient with the A and B mobile phases listed in table 2-1 below (Meyer and others, 2007). The initial flow rates of the $\mathrm{A}$ and $\mathrm{B}$ mobile phases were decreased and contained a higher proportion of the B mobile phase to assist in eluting the Prospekt SPE cartridge. During the elution, the LC autosampler injected $20 \mu \mathrm{L}$ of the internal standard. The isocratic mobile phase was used to increase the aqueous phase in the mobile phase stream to focus the compounds eluted from the SPE cartridge onto the head of the LC column. After the mobile phase flow had passed through the SPE cartridge, the flow rate was increased to $0.36 \mathrm{~mL} / \mathrm{min}$, and the isocratic pump flow was turned off. A $3.0 \times 150 \mathrm{~mm}$ Luna C18(2) (Phenonomenex) with $3-\mu \mathrm{m}$ packing was used to separate the antibiotics for each of the three methods. The LC column was rinsed for 5 minutes with 100 percent mobile phase $\mathrm{B}$ at the end of the gradient and then equilibrated at initial conditions for 5 minutes before the next sample analysis.

Table 2-1. Mobile phases used in the liquid chromatography/electrospray ionizationmass spectrometry (LC/ESI-MS) techniques for three common antibiotic groups.

$[\%$, percent $]$

\begin{tabular}{llll}
\hline \multirow{2}{*}{$\begin{array}{c}\text { Mobile-phase } \\
\text { name }\end{array}$} & Tetracyclines & \multicolumn{3}{c}{$\begin{array}{c}\text { Antibiotic groups } \\
\text { qulfonamides and } \\
\text { quinolones }\end{array}$} & $\begin{array}{c}\text { Macrolides and } \\
\text { beta lactams }\end{array}$ \\
\cline { 2 - 4 } $\mathrm{A}$ & $0.3 \%$ formic acid & $0.3 \%$ formic acid & $5 \mathrm{mM} \mathrm{NH}_{4}$-acetate \\
$\mathrm{B}$ & $1.0 \%$ formic acid & Acetonitrile & $\begin{array}{l}\text { Acetonitrile } \\
\text { Isocratic }\end{array}$ \\
\hline
\end{tabular}





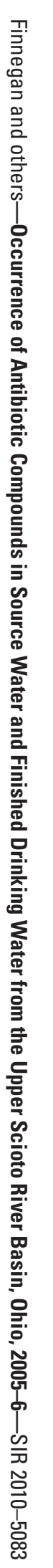

